\title{
K-Ar dating, geochemical and Sr-Nd-Pb isotopic systematics of Paleocene mafic rocks in Central Jiangxi, SE China: Evidence for lithosphere replacement
}

\author{
Guiqing Xie, ${ }^{1,2,3 *}$ Jingwen MaO, ${ }^{2}$ Ruizhong Hu,${ }^{3}$ Pirajno Franco, ${ }^{4}$ Ruiling $\mathrm{LI}^{3}$ and Jinjian CaO ${ }^{5}$ \\ ${ }^{1}$ State Key Laboratory of Geological Process and Mineral Recourse, China University of Geosciences, Beijing 100083, China \\ ${ }^{2}$ Institute of Mineral Resources, Chinese Academy of Geological Sciences, Beijing 100037, China \\ ${ }^{3}$ State Key Laboratory of Ore Deposit Geochemistry, Institute of Geochemistry, Chinese Academy of Sciences, \\ Guiyang 550002, China \\ ${ }^{4}$ Geological Survey of Western Australia, 100 Plain Street, Perth, WA 6004, Australia \\ ${ }^{5}$ Earth Science Departments, Sun Yat-Sun University, Guangzhou 510275, China
}

(Received August 16, 2005; Accepted April 19, 2005)

\begin{abstract}
Geochemical and isotopic studies were carried out on Paleocene mafic rocks in the Taihe Basin, central Jiangxi, Southeast China, in order better to understand their magma sources and tectonic implications. K-Ar dating results show that these mafic rocks intruded during the Paleocene (50-65 Ma). These Paleocene mafic rocks are porphyritic diabase and have similar geochemical features, such as strong enrichment of large ion lithophile element (LILE, e.g., Rb, Ba, Sr), slight enrichment of light rare earth element (LREE) and high field strength element (HFSE, e.g., Nb, Ta, Ti, P). The mafic rocks are also characterized by high rare earth element $(\mathrm{REE})$ and minor Eu anomalies $(\delta \mathrm{Eu}=0.88-1.2)$ and have uniform initial ${ }^{87} \mathrm{Sr} /{ }^{86} \mathrm{Sr}(0.7041-0.7064)$ and $\mathrm{Pb}$ isotopic composition $\left({ }^{206} \mathrm{~Pb} /{ }^{204} \mathrm{~Pb}=18.338-18.677\right)$ as well as a relatively wide range of initial $\mathrm{Nd}$ isotopic ratios $\left(\varepsilon_{\mathrm{Nd}}(\mathrm{T})\right)$ varying from +0.8 to +6.2 . These geochemical characteristics are different from those of subduction-related basalts, but similar to oceanic island basalts (OIB). Geochemical and isotopic evidence suggests that mafic rocks in the Taihe Basin were not significantly affected by crustal contamination and originated from asthenospheric mantle with a minor involvement of EM 2 mantle component. It is noted that Cretaceous basaltic rocks in Southeast China show enriched geochemical and isotopic compositions and were derived from a highly heterogeneous lithospheric mantle with minor asthenosphere components. On the other hand, Late Cenozoic basalts in Southeast China, which display OIB-like geochemical characteristics, were probably generated by melting of depleted asthenospheric mantle (DMM or MORB) with an involvement of EM 2 lithospheric mantle and a paucity of EM 1 lithospheric mantle. The Paleocene mafic rocks of the Taihe Basin exhibit transitional geochemical features between Cretaceous and Late Cenozoic basaltic magmatism, indicating that the involvement of asthenospheric mantle beneath Southeast China increased with time from Late Mesozoic to Cenozoic. It is suggested that the lithosphere replacement beneath Southeast China was associated with lithosphere extension and thinning, with decompression melting of the upwelling asthenosphere having taken place during the Paleocene period. Lithosphere replacement might be related to subduction roll-back or/and steepening of Paleo-Pacific plate due to injection of asthenospheric material into the mantle wedge beneath Southeast China.
\end{abstract}

Keywords: mafic rocks, $\mathrm{Sr}-\mathrm{Nd}-\mathrm{Pb}$, lithosphere replacement, Paleocene, Central Jiangxi

\section{INTRODUCTION}

The Late Mesozoic and Cenozoic in Southeast China were characterized by intensive and widespread magmatism. Volumetrically dominant granitoids and rhyolites, with minor basaltic rocks were emplaced between the Jurassic and the Cretaceous (Zhou and Li, 2000), whereas predominantly basaltic rocks of Late Cenozoic ages were erupted in the coastal region of South-

\footnotetext{
*Corresponding author (e-mail: guiqingxie@sohu.com) Copyright (c) 2006 by The Geochemical Society of Japan.
}

east China (e.g., Zou et al., 2000; Ho et al., 2003) (Fig. 1a). Recent studies have indicated that magma sources responsible for the Late Mesozoic magmatism are different from those of the Late Cenozoic basalts in Southeast China (Xie et al., 2001, 2005a). Studies of mantlederived xenoliths suggest that sub-continental lithospheric mantle beneath Southeast China is of Phanerozoic age (Zheng et al., 2004) and that ancient lithospheric mantle, up to $200 \mathrm{~km}$ thickness, had been removed and replaced by thinner, hotter and more fertile mantle material between the Late Mesozoic and the Cenozoic (Xu et al., 2000, 2002). This replacement might not have been complete throughout the region (Xu et al., 2002), because relicts of ancient lithospheric mantle (Middle Proterozoic, 

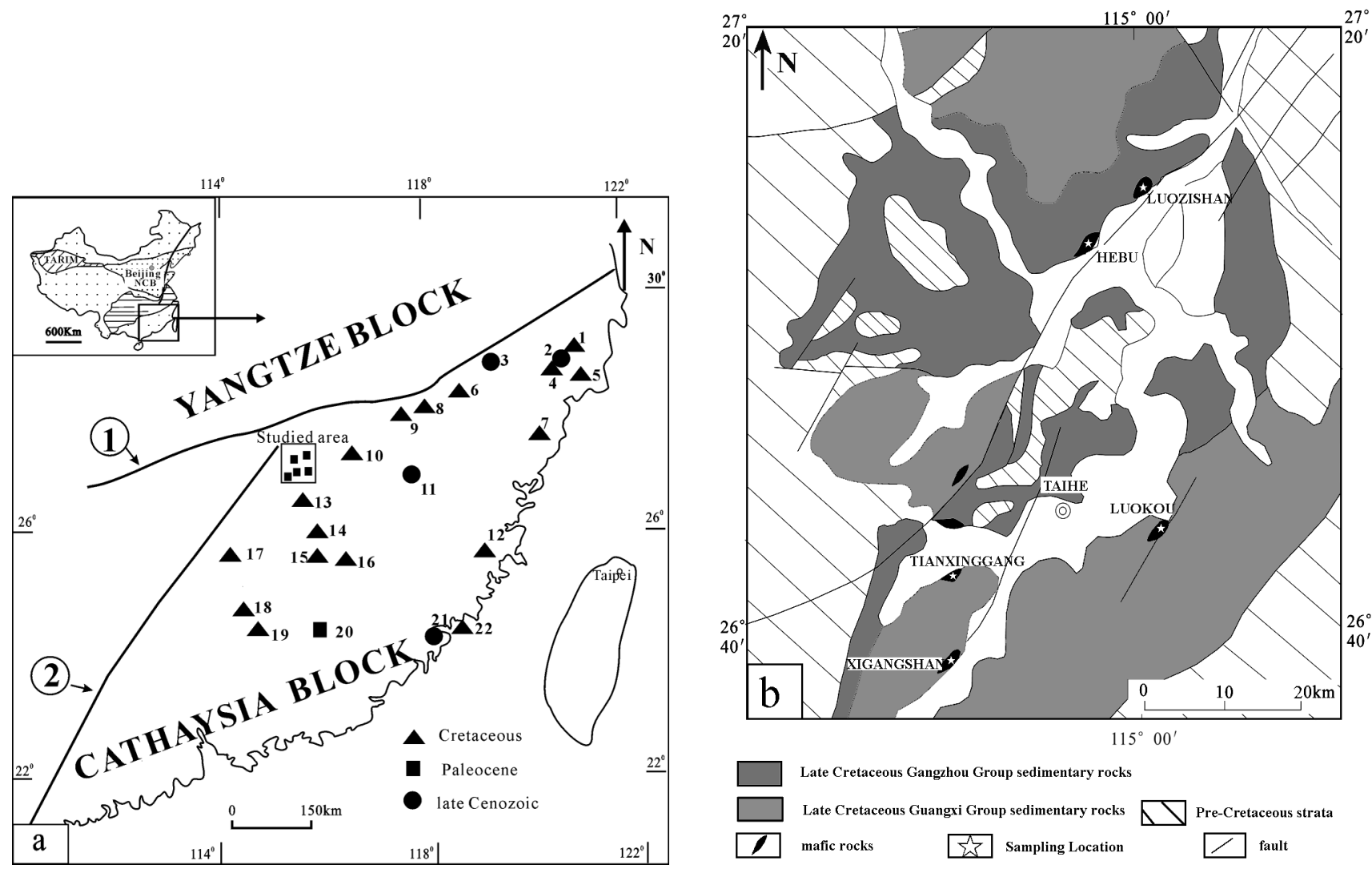

Fig. 1. (a) Spatial distribution of Late Mesozoic and Cenozoic basaltic magmatism in Southeast China (modified from Wang et al., 2003; Xu and Xie, 2005; Xie et al., 2006): (1) - Jiangshan-Shaoxing fault zone; (2) - Chenxian-Linwu fault zone. 1 - Xuanwudi basalt (110.3 Ma, Rb-Sr isochron age, Yu et al., 1993); 2 - Xinchang basalt (4.9-9.4 Ma, ${ }^{40} \mathrm{Ar}-{ }^{39}$ Ar plateau ages, Ho et al., 2003); 3 - Longyou basalt (Late Cenozoic, Xu and Xie, 2005); 4 - Jingling basalt (113 Ma, Rb-Sr isochron age, Xing et al., 2004); 5 - Xiangshan basalt (120 Ma, Rb-Sr isochron age, Xu and Xie, 2005); 6 - Yushan basalt (98-102 Ma, K-Ar ages, Wang et al., 2002); 7 - Guangtong Formation basalt (110 Ma, Rb-Sr isochron age, Zhou et al., 1993); 8 - Wuyishan mafic dikes (105.7-118.5 Ma, $\mathrm{K}$-Ar ages, Xie et al., 2006); 9 - Danyan mafic dikes (110.4 Ma, K-Ar age, Xie et al., 2006); 10 - Maopai mafic dikes (108.5 Ma, K-Ar age, Xie et al., 2006); 11 - Mingxi basalt (2.2 Ma, ${ }^{40} \mathrm{Ar}-{ }^{39}$ Ar plateau age, Ho et al., 2003); 12 - Yongtai basalt (103.0 Ma, zircon LA-ICPMS age, Xu and Xie, 2005) 13 - Shandai mafic dikes (100.2 Ma, K-Ar age, Xie et al., 2006); 14 - Caotaobei mafic dikes (92.1 Ma, K-Ar age, Xie et al., 2006); 15 - Yanbei mafic dikes (78.6-91.7 Ma, K-Ar ages, Xie et al., 2006); 16 - Huichang basalt (84.6 Ma, Rb-Sr isochron age, Zhou et al., 1998); 17 - Hengshan basalt (124.5-127.6 Ma, K-Ar ages, Wang et al., 2003); 18 - Daijishan mafic dikes (139.9-147.5 Ma, K-Ar ages, Li and McCulloch, 1998; Xie et al., 2006); 19 - North Guangdong mafic dikes (141.0-81.0 Ma, K-Ar ages, Li and McCulloch, 1998); 20 - Sanshui and Heyuan basalt (64-43 Ma, K-Ar ages, Chung et al., 1997; Zhu and Wang, 1989; Zhu et al., 2004); 21 - Niutoushan basalt (14.9-17.1 Ma, ${ }^{40}$ Ar- ${ }^{39}$ Ar plateau ages, Ho et al., 2003); 22 - Chinmen and Liehyu Islands mafic dikes (97.8 Ma ${ }^{40} \mathrm{Ar}-{ }^{39}$ Ar plateau age, Lan et al., 1995). (b) Simplified geologic map of Paleocene mafic rocks (modified from Zheng and Zhang, 1996) in Central Jiangxi, Southeast China.

and possibly as early as Late Archean; Wang and O'Reilly, 2003) may have survived lithospheric thinning during the Late Mesozoic (Wang and O'Reilly, 2003). This is also suggested by seismic and geothermal data (Hu et al., 2000; Yang, 2003; Yu et al., 2003a), which show that old lithospheric remnants are present in the uppermost layers of the lithosphere (Xu et al., 2002). Nevertheless, the timing and mechanisms for this event remain poorly understood, owing to the lack of knowledge about the nature of the mantle source during the Paleocene that links
Late Mesozoic to Late Cenozoic magmatism in Southeast China.

In contrast to Late Cenozoic basalts, only sparse outcrops of Paleocene mafic rocks occur in East China largely because of the thick Quaternary cover (Fan and Hooper, 1991). The available geochemical data on Paleocene mafic rocks were obtained from core samples from oil wells in the Subei and Liaohe basins and the North China Caton (Yang et al., 1998; Cong et al., 2001; Shen et al., 2002). However, during recent geological surveys in Southeast 
China, Paleocene mafic rocks have been found in the Taihe basin, Central Jiangxi (BGMRJX, 1995a, b, c, d, e).

Paleocene mafic rocks together with Cretaceous and Late Cenozoic basaltic rocks provide a good opportunity to study the changing nature of the mantle source with time and investigate the implications for lithospheric replacement in Southeast China.

\section{Geological Setting}

Southeast China comprises the Cathaysia Block in the southeast and the Yangtze Block in the northwest, separated by the Jianshan-Shaoxing fault (Zhang et al., 2005), and the Chenzhou-Linwu fault, representing the Mesozoic lithospheric boundary between the Yangtze Block and Cathaysia Block (Wang et al., 2003). These two tectonic units were amalgamated in the Neoproterozoic (e.g., Li, 1999). The Cathaysia Block has a complex tectono-magmatic history and was mainly developed on a Precambrian (Paleoproterozoic to Mesoproterozoic, and possibly late Archaean) metamorphic basement (Chen and Jahn, 1998). This ancient basement was unconformably overlain by Sinian marine clastic rocks and dolomite, Paleozoic marine carbonate and clastic rocks, and Early Mesozoic sandstone and shale. The Cathaysia Block was affected by Late Mesozoic magmatism, which is widespread in Southeastern China, and then followed by Late Cenozoic basalts erupted along the coastal region. Some of these basalts contain abundant mantle-derived xenoliths ( $\mathrm{Xu}$ et al., 2000, 2002, 2003; Yu et al., 2003a; Wang and O'Reilly, 2003; Zheng et al., 2004).

Paleozoic to Lower Triassic shallow-marine carbonates, clastic deposits, and flysch sequences were unconformably overlain by Mesozoic volcano-sedimentary rocks that accumulated in rift basins. These basins were formed since the Middle Jurassic, and contain volcanic rocks that are dominantly characterized by basalts and rhyolites with minor andesite-dacites in CentralSouthern Jiangxi (Wang et al., 2004, 2005). In addition, minor Jurassic gabbroic intrusions are also present in Southern Jiangxi, as exemplified by Middle Jurassic Chebu intrusion (Li et al., 2003; Xie et al., 2005b). Also present in Central- Southern Jiangxi are Late Mesozoic granitic rocks and minor Cretaceous basalts and associated mafic dikes (Li and McCulloch, 1998; Zhou and Li, 2000; Wang et al., 2003; Peng et al., 2004; Yu et al., 2005; Xie et al., 2006). Several Cretaceous to Tertiary rift basins in Central Jiangxi, contain red mudstone and sandstone with minor mafic intrusions (BGMRJX, 1984; Zhou and $\mathrm{Li}, 2000$ ). One of these is the Late Cretaceous Taihe basin, with an area of $4000 \mathrm{~km}^{2}$ (Gilder et al., 1991; Zheng and Zhang, 1996; Zhou and Li, 2000; Yu et al., 2005) in which samples for this study were collected from five localities, namely: Luozishan, Hebu, Tianxinggang, Luokou
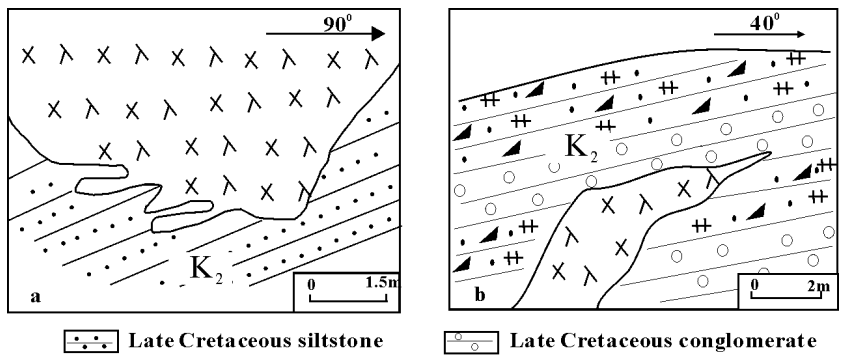

Late Cretaceous feldsparsand stone mafic rocks

Fig. 2. Sketch map showing spatial relationships between mafic rocks and Late Cretaceous sedimentary rocks in Central Jiangxi. Southeast China (a) and (b) modified after 1:50 000 Futian and Taihe geological maps, respectively (BGMRJX, 1995a, b).

and Xigangshan (Fig. 1b). The mafic intrusive rocks in the Taihe basin commonly have elliptical to lensoid shapes (Fig. 1b) and are emplaced in the Late Cretaceous Yulou Formation (siltstone and feldspathic sandstone) and Honggang Formation (mainly conglomerate) in the lower part of Guangxi Group (95-80 Ma) (Liu and Li, 2001), and Zhoutai Formation (siltstone and mudstone) of Gangzhou Group (100-95 Ma) (Liu and Li, 2001) (Fig. 2 ). The contact between the mafic intrusions and the host rocks is sharp, and chilled margins are present with widths ranging from several $\mathrm{cm}$ to tens of centimeters (BGMRJX, 1995a, b, c, d, e). All samples in this study are generally fresh. The studied mafic rocks are porphyritic diabase, predominantly composed of plagioclase (40-50\%), clinopyroxene $(25-35 \%)$ and olivine (5-15\%) with minor Ti-magnetite (5\%). Olivine is an almost ubiquitous phenocryst phase, locally occurring together with clinopyroxene and plagioclase. The groundmass ranges from glassy to cryptocrystalline, and identifiable minerals in it are olivine, plagioclase, clinopyroxene and magnetite. These mafic rocks are generally unaltered, but in some altered samples olivine grains are replaced by iddingsite along minerals cracks; whereas clinopyroxene and plagioclase are replaced by minor chlorite.

\section{Analytical Methods}

Major element analyses were carried out by a conventional wet chemical method at the Chemical Analytical Center, Institute of Geochemistry, Chinese Academy of Sciences (IGCAS). The analytical errors for major oxides are generally less than $2 \%$. Trace elements and rare earth elements abundances were determined by solution ICP-MS performed at the ICP-MS Laboratory, Institute of Geochemistry, Chinese Academy of Sciences (IGCAS). The samples were digested by acid ( $\mathrm{HF}+$ $\mathrm{HClO}_{4}$ ) in bombs. Precision for most elements was typi- 
Table 1. K-Ar dating results for mafic rocks in the Taihe Basin, Central Jiangxi, SE China

\begin{tabular}{llccccc}
\hline Sample No. & Weight/g & $\mathrm{K}(\%)$ & ${ }^{40} \mathrm{Ar}^{*}\left(10^{-10} \mathrm{~mol} / \mathrm{g}\right)$ & ${ }^{40} \mathrm{Ar} *(\%)$ & ${ }^{40} \mathrm{Ar} *{ }^{40} \mathrm{~K}\left(10^{-3}\right)$ & $\mathrm{T}(\mathrm{Ma})$ \\
\hline LZS1 & 0.03207 & 1.08 & 0.9335 & 71.44 & 2.8959 & $49.2 \pm 0.9$ \\
JCX7 & 0.03053 & 0.90 & 0.7941 & 59.20 & 2.9564 & $50.2 \pm 1.2$ \\
XG1 & 0.02995 & 0.92 & 0.8060 & 55.77 & 2.9353 & $49.8 \pm 1.6$ \\
XG2 & 0.0316 & 0.97 & 1.0699 & 65.10 & 3.6955 & $62.5 \pm 1.9$ \\
LZX1 & 0.03164 & 1.45 & 1.3458 & 62.48 & 3.1098 & $52.7 \pm 1.2$ \\
LZX3 & 0.02996 & 1.24 & 1.3999 & 64.73 & 3.7826 & $64.0 \pm 1.0$ \\
TXG2 & 0.0279 & 1.81 & 1.9506 & 80.95 & 3.6108 & $61.1 \pm 1.4$ \\
TXG3 & 0.03009 & 1.79 & 2.0637 & 82.42 & 3.8627 & $65.3 \pm 1.1$ \\
\hline
\end{tabular}

Note: Sample Numbers with prefix letters for LZS, JCX, XG, LZX and TXG from Luozishan, Hebu, Xigangshan, Luokou and Tiangxinggang areas, respectively. Sample Numbers and locations are same as Tables 2 and 3.

cally better than $5 \%$ RSD. The measured values for $\mathrm{Zr}$, $\mathrm{Hf}, \mathrm{Nb}$ and $\mathrm{Ta}$ were less than $10 \%$ in error compared to certified values. Sample preparations, instrument operating conditions and calibration procedures follow those established by Qi and Grégoire (2000).

For Sr-Nd isotopic analyses, sample powders $(\sim 100$ $\mathrm{mg}$ ) were dissolved in distilled $\mathrm{HF}-\mathrm{HNO}_{3}$ in Savillex Screwtop Teflon beakers at $150 \mathrm{C}$ overnight. Sr and REE were separated on columns made of $\mathrm{Sr}$ and REE resins of the Eichrom Company using $0.1 \% \mathrm{HNO}_{3}$ as elutant. Separation of $\mathrm{Nd}$ from the REE fractions was carried out on HDEHP columns with a $0.18 \mathrm{~N} \mathrm{HCl}$ elutant. The isotopic analyses were performed using a Micromass Isoprobe multi-collector-ICPMS (MC-ICPMS) at Guangzhou Institute of Geochemistry, Chinese Academy of Sciences (GIGCAS). Measured $\mathrm{Sr}$ and $\mathrm{Nd}$ isotopic ratios were normalized using an ${ }^{86} \mathrm{Sr} /{ }^{88} \mathrm{Sr}$ value of 0.1194 and a ${ }^{146} \mathrm{Nd} /$ ${ }^{144} \mathrm{Nd}$ value of 0.7219 , respectively, ${ }^{87} \mathrm{Rb} /{ }^{86} \mathrm{Sr}$ and ${ }^{147} \mathrm{Sm} /$ ${ }^{144} \mathrm{Nd}$ ratios were calculated using the $\mathrm{Rb}, \mathrm{Sr}, \mathrm{Sm}$ and $\mathrm{Nd}$ abundances measured by ICP-MS. Analyses of standards during the period of analysis, are as follows: NBS987 gave ${ }^{87} \mathrm{Sr} /{ }^{86} \mathrm{Sr}=0.710243 \pm 14(2 \sigma)$; Shin Etou JNDi-1 gave ${ }^{143} \mathrm{Nd} /{ }^{144} \mathrm{Nd}=0.512124 \pm 11(2 \sigma)$, equivalent to a value of 0.511860 for the La Jolla international standard (Tanaka et al., 2000). For $\mathrm{Pb}$ isotope analyses, sample powders were spiked and dissolved in concentrated $\mathrm{HF}$ at $800^{\circ} \mathrm{C}$ for $72 \mathrm{~h}$. Lead was separated and purified by conventional anion-exchange technique (AG1 $\times 8,200-400$ resin) with diluted $\mathrm{HBr}$. Isotopic ratios were measured using the MAT-261 mass spectrometer at the Research Center for Geological Analysis, Institute of Uranium Geology (GAIUG). In-run analytical precision for $1 \mu \mathrm{g}{ }^{208} \mathrm{~Pb} /{ }^{206} \mathrm{~Pb}$ is better than $0.005 \%$. Repeated analyses of NBS 981 yielded ${ }^{208} \mathrm{~Pb} /{ }^{206} \mathrm{~Pb}=2.1652465 \pm 0.000069$, ${ }^{207} \mathrm{~Pb} /{ }^{206} \mathrm{~Pb}=0.9145100 \pm 0.000056$ and ${ }^{204} \mathrm{~Pb} /{ }^{206} \mathrm{~Pb}=$ $0.0591995 \pm 0.000013$. K-Ar dating was performed using the high sensitivity mass spectrometer (MM1200B) at the K-Ar and ${ }^{40} \mathrm{Ar}-{ }^{39} \mathrm{Ar}$ Isotopic Laboratory of Institute of Geology, China Academy of Geological Society
(IGCAGS). The analytical result for Chinese standard $\mathrm{ZBH}-25$ is $132.5 \pm 1.6 \mathrm{Ma}$ (recommended age $132.7 \mathrm{Ma}$ ). The age calculation parameters used are $K^{40}=0.1167 \%$, $K_{\mathrm{e}}=5.811 \times 10^{-11} /$ year and $K_{\mathrm{b}}=4.962 \times 10^{-10} /$ year. K$\mathrm{Ar}$ dating results, major and trace element composition and $\mathrm{Nd}-\mathrm{Sr}-\mathrm{Pb}$ isotopic data for mafic rocks in Central Jiangxi, SE China are listed in Tables 1 to 3, respectively.

\section{RESULTS}

Emplacement ages of Paleocene mafic rocks

Samples of mafic intrusions in the Taihe Basin yield K-Ar ages (Table 1) of 52.7-64.0 Ma (Luokou), 49.2 Ma (Luozishan), 50.2 Ma (Hebu), 61.1-65.3 Ma (Tianxinggang) and 49.8-62.5 Ma (Xigangshan). These results are consistent with previous results of K-Ar dating of samples from Luokou, Tianxinggang and Xigangshan which yielded 55.9 Ma, 62.6-63.1 Ma and 63.52 Ma, respectively (BGMRJX, 1995a, b, e; Yu et al., 2005 ) and Sm-Nd model ages of $62 \pm 2 \mathrm{Ma}$ (Liu and $\mathrm{Li}$, 2001). The mafic rocks intruded the Late Cretaceous Yulou Formation and Honggang Formation in the lower part of Guangxi Group (95-80 Ma) and Zhoutai Formation of Gangzhou Group (100-95 Ma) (Liu and Li, 2001) in the Hebu, Tianxingang and Luokou region (BGMRJX, 1995a, b, d), implying that these mafic rocks are not earlier than $80 \mathrm{Ma}$ in age. Although one sample from Luozishan gives a ${ }^{40} \mathrm{Ar} /{ }^{39} \mathrm{Ar}$ plateau age of $90.2 \pm 0.3 \mathrm{Ma}$ (Peng et al., 2004), both geological evidence and age dating in this study confirm that these mafic rocks in Central Jiangxi were intruded in the Paleocene.

\section{Major and trace element data}

The Taihe Basin Paleocene mafic rocks are characterized by a wide range of $\mathrm{SiO}_{2}(45.01-51.67 \%)$ and $\mathrm{K}_{2} \mathrm{O}+$ $\mathrm{Na}_{2} \mathrm{O}(3.11-6.20 \%)$, low $\mathrm{CaO}(5.96-9.28 \%)$ and $\mathrm{K}_{2} \mathrm{O} /$ $\mathrm{Na}_{2} \mathrm{O}(0.24-0.59)$ abundances, but high $\mathrm{Na}_{2} \mathrm{O}(2.36-$ $4.36 \%)$ contents.

In the total alkali versus silica classification of Irvine 


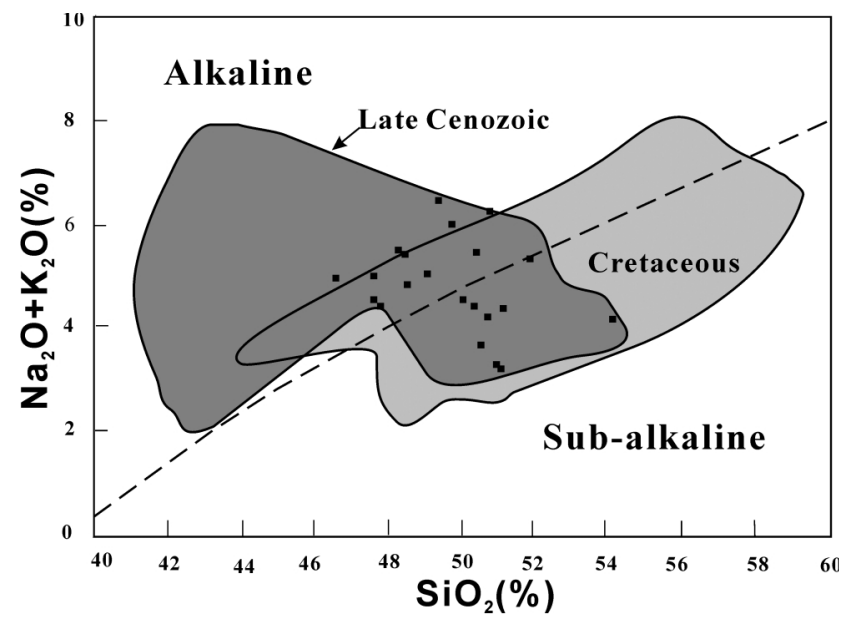

Fig. 3. Total alkalis $\left(\mathrm{K}_{2} \mathrm{O}+\mathrm{Na}_{2} \mathrm{O}\right)$ versus $\mathrm{SiO}_{2}$ diagram for Paleocene mafic rocks in the Taihe Basin, Central Jiangxi, Southeast China. The division between alkaline and sub-alkaline is after Irvine and Baragar (1971). The fields of Cretaceous mafic rocks and basalts (e.g., Lan et al., 1995; Lapierre et al., 1997; Li and McCulloch, 1998; Xiong et al., 2003; Wang et al., 2003; Xie et al., 2006) and Late Cenozoic basalts (e.g., Flower et al., 1992; Qi et al., 1994; Liu et al., 1994; Zou et al., $2000)$ in Cathaysia Block are shown for comparison.

and Baragar (1971) these rocks plot in the alkaline to subalkaline fields (Fig. 3). Large variations in $\mathrm{MgO}$ (5.43$8.87 \%), \mathrm{Cr}(68.0-212 \mathrm{ppm})$ and $\mathrm{Ni}(74.7-205 \mathrm{ppm})$, point to variable fractional crystallization during the magmatic evolution. This is also supported by correlations between $\mathrm{SiO}_{2}, \mathrm{MgO}$, other major oxides and trace elements (Fig. 4). For example, all samples show negative correlations between $\mathrm{SiO}_{2}$ and $\mathrm{TiO}_{2}$ and $\mathrm{P}_{2} \mathrm{O}_{5}$ (Figs. 4a and c), which suggests fractionation of ilmenite, apatite and clinopyroxene (Wilson, 1989). Compatible elements such as $\mathrm{Cr}$ and $\mathrm{Ni}$ decrease with $\mathrm{MgO}$ in the mafic rocks (Figs. $4 \mathrm{~d}$ and $\mathrm{f}$ ), implying fractional crystallization of olivine and clinopyroxene (Wilson, 1989). Positive correlations between $\mathrm{CaO} / \mathrm{Al}_{2} \mathrm{O}_{3}$ and $\mathrm{CaO}$ (Fig. 4e) are also indicative of fractional crystallization of clinopyroxene (Qi $e t$ al., 1994).

The mafic rocks show high REE patterns (Fig. 5) that are characterized by strong LREE enrichment with minor Eu anomalies $\left(\mathrm{Eu} / \mathrm{Eu}^{*}=0.88-1.2\right.$; Table 2$)$, variable $\mathrm{La}_{\mathrm{N}} / \mathrm{Yb}_{\mathrm{N}}$ (4.8-14.6) and LREE/HREE ratios (5.0-10.0). The abundances of incompatible trace elements for these rocks are higher than those for Primitive Mantle (PM) and Mid-ocean ridge basalt (MORB) (Sun and McDonough, 1989). The mafic rocks exhibit strong enrichment of large ion lithophile elements (LILE) (Ba, Sr, $\mathrm{K}$ and $\mathrm{Rb}$ ), LREE, slight enrichment of high strength field elements (HSFE) (Nb, Ta, Zr, Hf) and incompatible trace element patterns. These geochemical features resemble
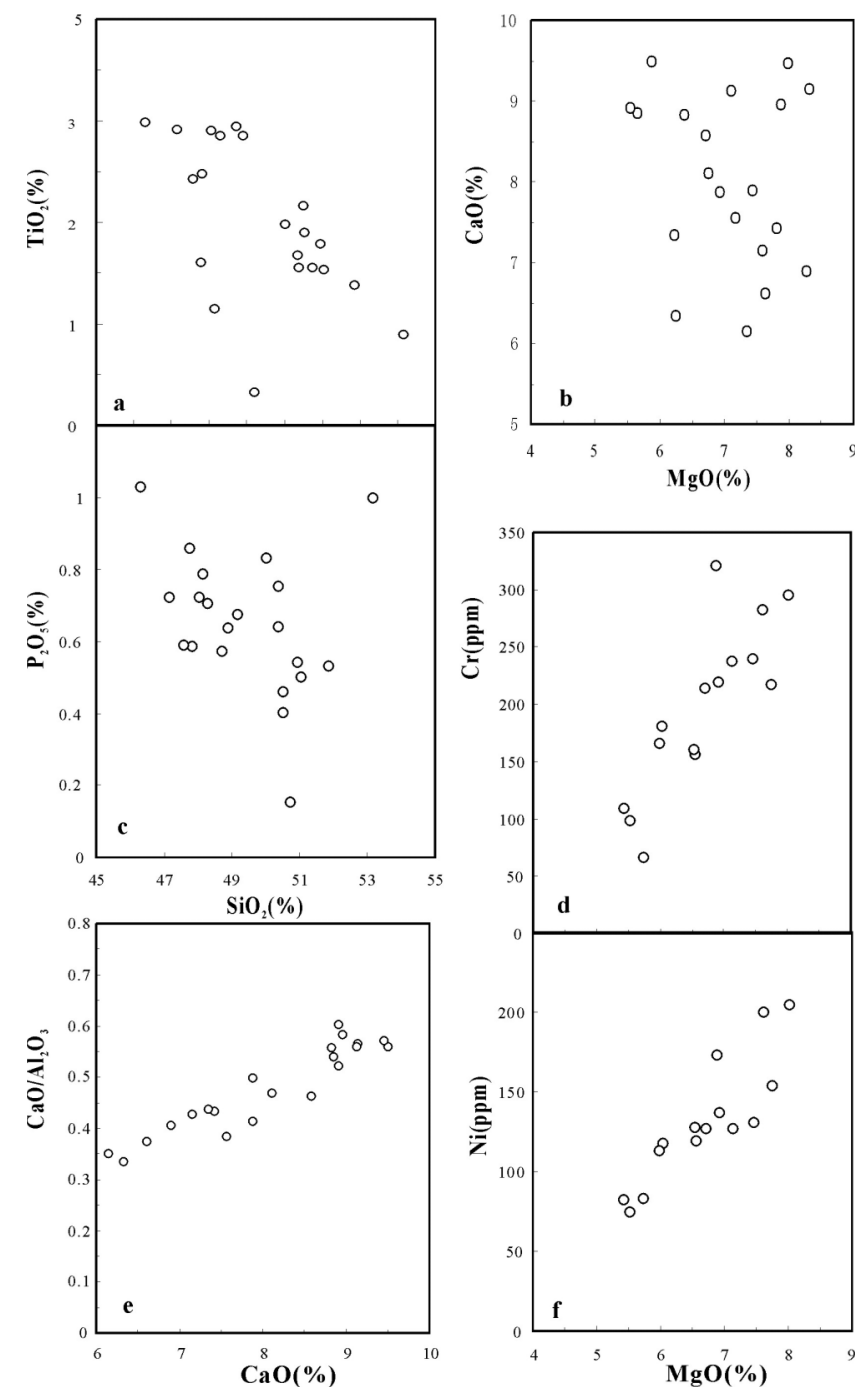

Fig. 4. Harker-type diagrams of trace elements versus major elements for Paleocene mafic rocks in the Taihe Basin, Central Jiangxi, Southeast China.

those of ocean island basalt (OIB) (Sun and McDonough, 1989) (Fig. 6). The mafic rocks also have relatively high $\mathrm{Nb} /$ La ratios (1.1-1.6), distinguishing them from continental arc basalts (McCulloch and Gamble, 1991). It is noted that the MORB normalized trace element patterns for these samples (Fig. 6) are similar to those of Late Cenozoic basalts in Southeast China (Peng et al., 1986; Flower et al., 1992; Liu et al., 1994; Qi et al., 1994; Chung et al., 1994, 1995; Zou et al., 2000; Ho et al., 2003). The MORB-normalized multielement diagrams display small differences, for example the Luokou mafic rocks exhibit weak $\mathrm{Rb}$ positive anomalies and minor $\mathrm{Ba}$ negative anomalies, while the Tianxinggang rocks show weak $\mathrm{Ba}$ positive anomalies and minor $\mathrm{Rb}$ negative anomalies. 


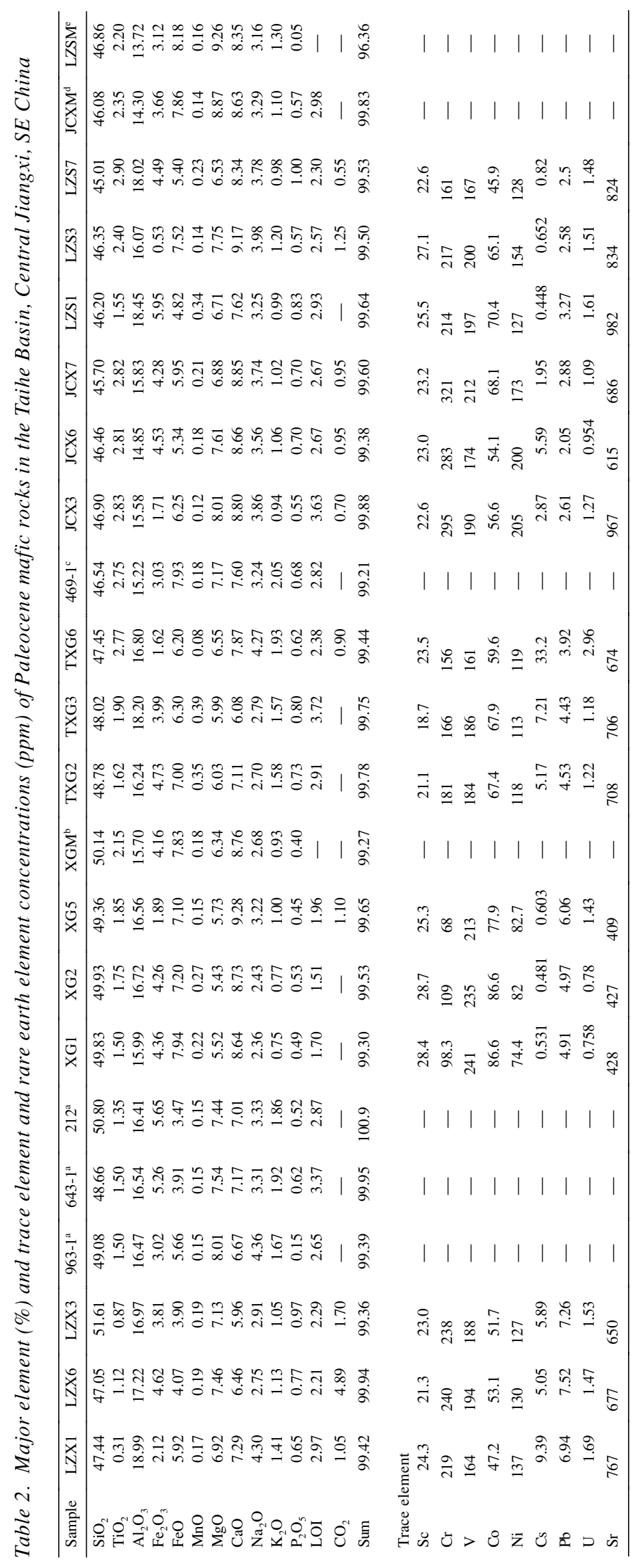




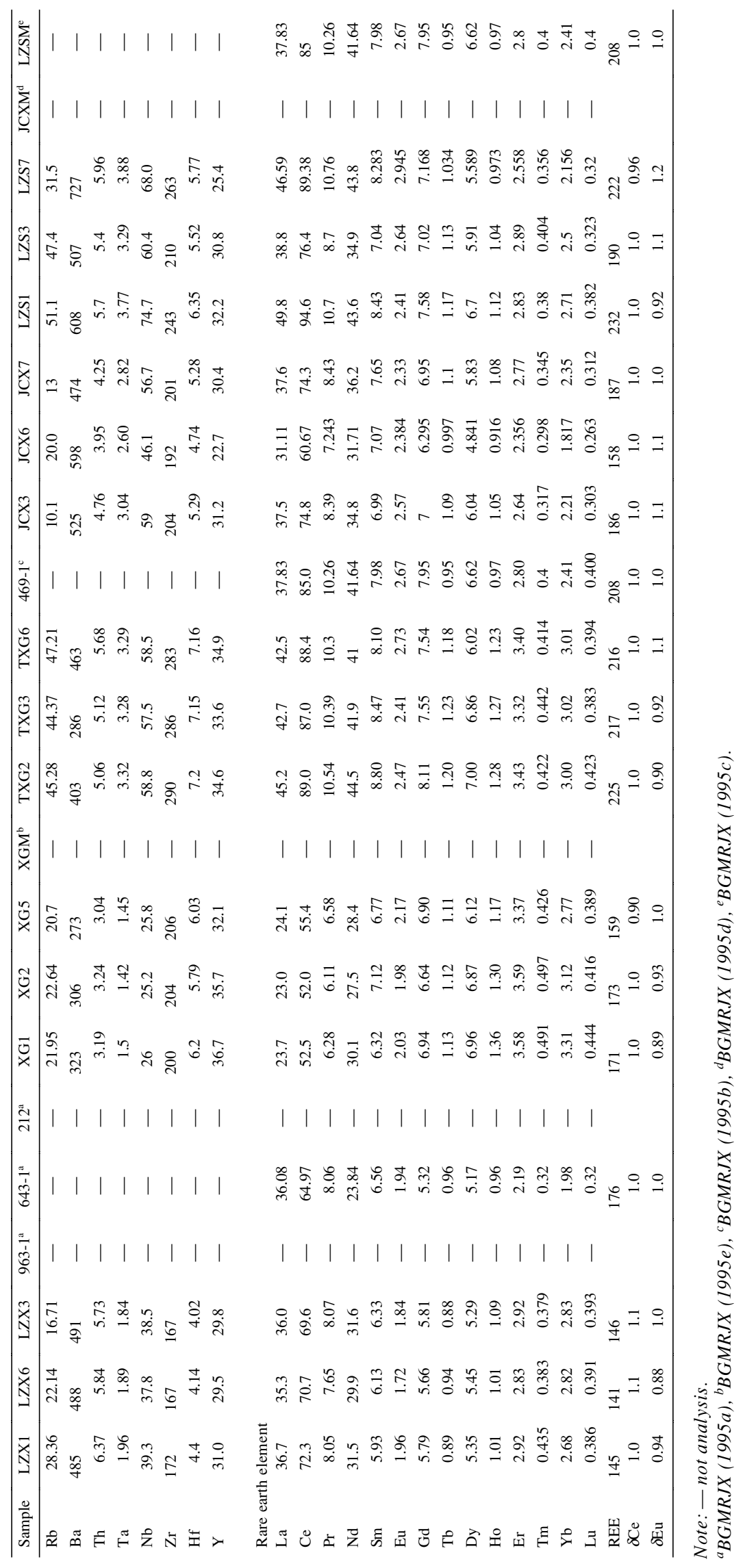



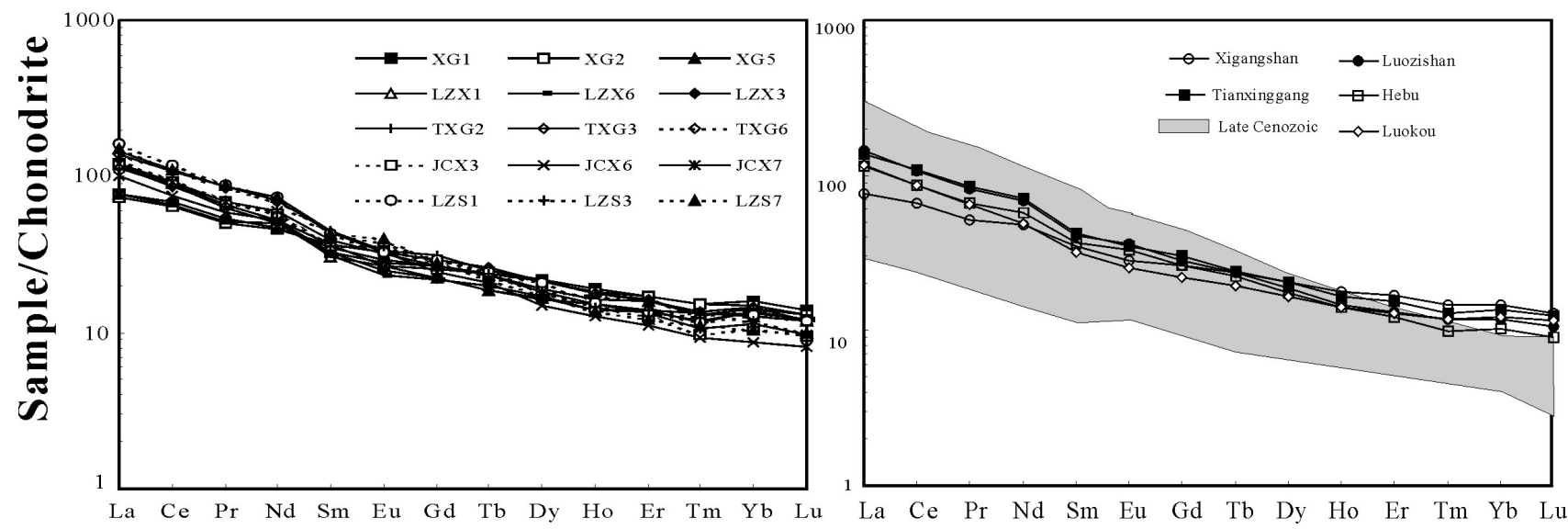

Fig. 5. Chondrite-normalized REE patterns for Paleocene mafic rocks in the Taihe Basin, Central Jiangxi, Southeast China. Normalization values after Boynton (1984). Field of Late Cenozoic basalts (e.g., Flower et al., 1992; Qi et al., 1994; Liu et al., 1994; Zou et al., 2000) in Cathaysia Block are shown for comparison.
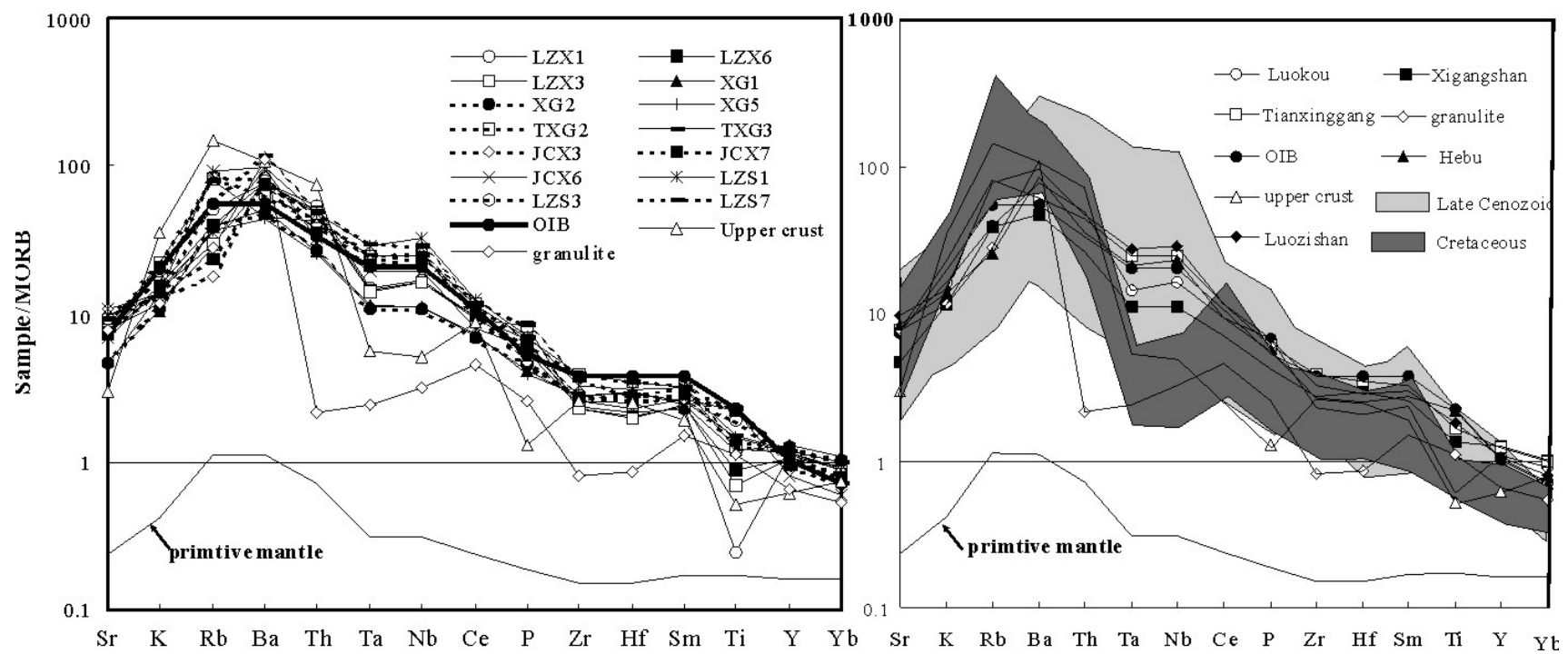

Fig. 6. MORB-normalized incompatible element plots for Paleocene mafic rocks in the Taihe Basin, Central Jiangxi, Southeast China. MORB, Primitive mantle (PM) and OIB values after Sun and McDonough (1989), upper crust and granulite in the Southeast China after Gao et al. (1998) and Yu et al. (2003b), respectively. The fields of Cretaceous basalts and mafic dikes (e.g., Lan et al., 1995; Lapierre et al., 1997; Xiong et al., 2003; Ge et al., 2003; Wang et al., 2003; Xie et al., 2006) and Late Cenozoic basalts (e.g., Flower et al., 1992; Qi et al., 1994; Liu et al., 1994; Zou et al., 2000) in Cathaysia Block are shown for comparison.

\section{$\mathrm{Sr}-\mathrm{Nd}$-Pb isotope data}

The Taihe Basin mafic rocks have relatively high initial ${ }^{87} \mathrm{Sr} /{ }^{86} \mathrm{Sr}$ ratios from 0.7041 to 0.7064 , whereas $\mathrm{Nd}$ isotopes are heterogeneous, with $\varepsilon_{\mathrm{Nd}}(\mathrm{T})$ ranging from +0.8 to +6.2 . The $\varepsilon_{\mathrm{Nd}}(\mathrm{T})$ values, as shown in Table 3 , are $+1.7-$ +1.9 (samples from Luokou), +0.8 (Luozishan), +6.2 (Hebu), +4.7-+4.9 (Tianxinggang) and +1.6-2.0 (Xigangshan). The $\mathrm{Sr}-\mathrm{Nd}$ isotopic correlation diagrams (Fig. 7) show that they plot within the OIB field, similar to those of Samoan and Society Island Basalts, which contain relatively high EM 2 mantle component (Zindler and Hart, 1986). The ${ }^{208} \mathrm{~Pb} /{ }^{204} \mathrm{~Pb}$ ratios for the Paleocene mafic rocks, as shown in Table 3, are 36.919 to 37.150 (Luokou), 36.824 (Luozishan), 36.787 (Hebu), 38.692 to 38.807 (Tianxinggang) and 38.714 to 38.898 (Xigangshan), whereas they have similar ${ }^{206} \mathrm{~Pb} /{ }^{204} \mathrm{~Pb}$ and ${ }^{207} \mathrm{~Pb} /{ }^{204} \mathrm{~Pb}$ ratios of $18.338-18.677$ and $15.443-15.636$, respectively (Table 3 ). 
Table 3. Pb, Sr and Nd isotopic compositions of Paleocene mafic rocks in the Taihe Basin, Central Jiangxi, SE China

\begin{tabular}{lllllllll}
\hline Sample No. & \multicolumn{1}{c}{ XG1 } & \multicolumn{1}{c}{ XG2 } & \multicolumn{1}{c}{ TXG2 } & \multicolumn{1}{c}{ TXG3 } & \multicolumn{1}{c}{ LZX1 } & \multicolumn{1}{c}{ LZX3 } & LZS1 \\
\hline $\mathrm{U}(\mathrm{ppm})$ & 0.758 & 0.78 & 1.22 & 1.18 & 1.69 & 1.53 & 1.61 & 1.09 \\
$\mathrm{~Pb}(\mathrm{ppm})$ & 4.91 & 4.97 & 4.53 & 4.43 & 6.94 & 7.26 & 3.27 & 2.88 \\
$\mathrm{Th}(\mathrm{ppm})$ & 3.19 & 3.24 & 5.06 & 5.12 & 6.37 & 5.73 & 5.70 & 4.25 \\
${ }^{208} \mathrm{~Pb} /{ }^{204} \mathrm{~Pb}(2 \sigma)$ & $39.021 \pm 14$ & $38.838 \pm 10$ & $39.02 \pm 25$ & $38.912 \pm 39$ & $37.321 \pm 22$ & $37.065 \pm 19$ & $37.147 \pm 90$ & $37.059 \pm 25$ \\
${ }^{207} \mathrm{~Pb} /{ }^{204} \mathrm{~Pb}(2 \sigma)$ & $15.617 \pm 6$ & $15.599 \pm 4$ & $15.610 \pm 10$ & $15.538 \pm 16$ & $15.643 \pm 9$ & $15.543 \pm 8$ & $15.457 \pm 37$ & $15.474 \pm 10$ \\
${ }^{206} \mathrm{~Pb} /{ }^{204} \mathrm{~Pb}(2 \sigma)$ & $18.767 \pm 7$ & $18.645 \pm 5$ & $18.762 \pm 12$ & $18.685 \pm 19$ & $18.643 \pm 10$ & $18.510 \pm 90$ & $18.684 \pm 45$ & $18.553 \pm 12$ \\
$\left({ }^{208} \mathrm{~Pb} /{ }^{204} \mathrm{~Pb}\right)_{\mathrm{i}}$ & 38.898 & 38.714 & 38.807 & 38.692 & 37.15 & 36.919 & 36.824 & 36.787 \\
$\left({ }^{207} \mathrm{~Pb} /{ }^{204} \mathrm{~Pb}\right)_{\mathrm{i}}$ & 15.613 & 15.594 & 15.603 & 15.531 & 15.636 & 15.538 & 15.443 & 15.464 \\
$\left({ }^{206} \mathrm{~Pb} /{ }^{204} \mathrm{~Pb}\right)_{\mathrm{i}}$ & 18.677 & 18.553 & 18.605 & 18.53 & 18.504 & 18.391 & 18.404 & 18.338 \\
$\mathrm{Rb}(\mathrm{ppm})$ & 21.9 & 22.6 & 44.4 & 45.3 & 28.4 & 16.7 & 51.1 & 13.0 \\
$\mathrm{Sr}(\mathrm{ppm})$ & 428 & 427 & 706 & 708 & 767 & 650 & 982 & 686 \\
${ }^{87} \mathrm{Rb} /{ }^{86} \mathrm{Sr}$ & 0.148 & 0.1531 & 0.1851 & 0.1819 & 0.1071 & 0.0743 & 0.1505 & 0.0548 \\
${ }^{87} \mathrm{Sr} /{ }^{86} \mathrm{Sr}(2 \sigma)$ & $0.706273 \pm 11$ & $0.706275 \pm 14$ & $0.70447 \pm 11$ & $0.704236 \pm 13$ & $0.706509 \pm 13$ & $0.705469 \pm 11$ & $0.705918 \pm 11$ & $0.704237 \pm 14$ \\
$\left({ }^{87} \mathrm{Sr} /{ }^{86} \mathrm{Sr}\right)_{\mathrm{i}}$ & 0.7062 & 0.7061 & 0.7043 & 0.7041 & 0.7064 & 0.7054 & 0.7058 & 0.7042 \\
$\mathrm{Sm}(\mathrm{ppm})$ & 6.32 & 7.12 & 8.47 & 8.8 & 5.93 & 6.33 & 8.43 & 7.65 \\
$\mathrm{Nd}_{(\mathrm{ppm})}$ & 30.1 & 27.5 & 41.9 & 44.5 & 31.5 & 31.6 & 43.6 & 36.2 \\
${ }^{147} \mathrm{Sm} /{ }^{144} \mathrm{Nd}$ & 0.1269 & 0.1565 & 0.1196 & 0.1222 & 0.1138 & 0.1211 & 0.1169 \\
${ }^{143} \mathrm{Nd} /{ }^{144} \mathrm{Nd}(2 \sigma)$ & $0.512718 \pm 8$ & $0.512702 \pm 8$ & $0.512846 \pm 8$ & $0.512862 \pm 9$ & $0.51270 \pm 9$ & $0.512695 \pm 8$ & $0.512653 \pm 10$ & 0.1278 \\
$\left({ }^{143} \mathrm{Nd} /{ }^{144} \mathrm{Nd}\right)_{\mathrm{i}}$ & 0.5127 & 0.5126 & 0.5128 & 0.5128 & 0.5127 & 0.5126 & 0.5126 & 0.5129 \\
$\varepsilon_{\mathrm{Nd}}(\mathrm{T})$ & 2.0 & 1.6 & 4.7 & 4.9 & 1.9 & 1.7 & 0.8 & 6.2 \\
\hline
\end{tabular}

Note: Initial ${ }^{143} \mathrm{Nd} /{ }^{144} \mathrm{Nd}$ and ${ }^{87} \mathrm{Sr} /{ }^{86} \mathrm{Sr}$ and $\mathrm{Pb}$ isotope are calculated using $\mathrm{K}$-Ar age. $\lambda_{U 238}=1.55125 \times 10^{-10} /$ year, $\lambda_{U 235}=9.8485 \times 10^{-10} /$ year, $\lambda_{\text {Th232 }}=4.9475 \times 10^{-11} /$ year, $\left({ }^{87} \mathrm{Sr} /{ }^{87} \mathrm{Sr}\right)^{0}{ }_{U R}=0.7045,\left({ }^{87} \mathrm{Rb} /{ }^{86} \mathrm{Sr}\right)^{0}{ }_{U R}=0.0827,\left({ }^{143} \mathrm{Sm} /{ }^{144} \mathrm{Nd}\right)^{0}{ }_{\mathrm{CHUR}}=0.51238,\left({ }^{143} \mathrm{Nd} /{ }^{144} \mathrm{Nd}\right)^{0}{ }_{\mathrm{CHUR}}=0.1967$; $\lambda_{R b}=1.42 \times 10^{-11} /$ year, $\lambda_{S m}=6.54 \times 10^{-12} /$ year (Rollinson, 1993$)$.

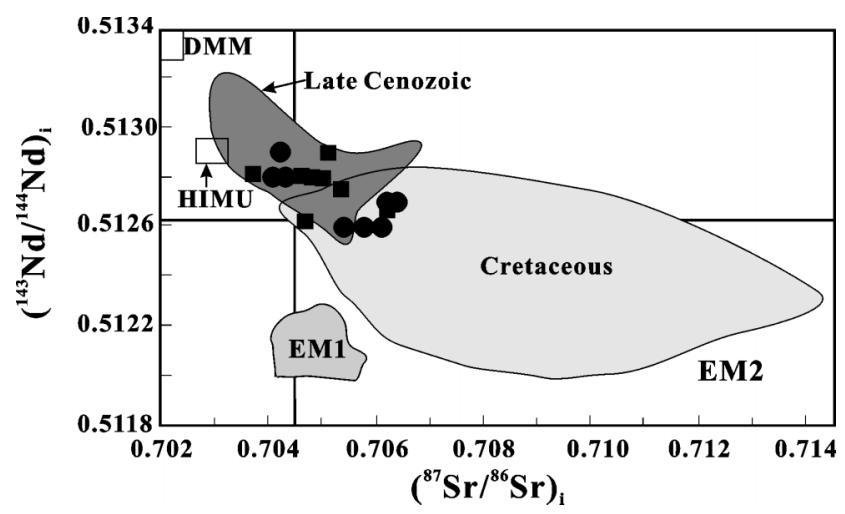

Fig. 7. Nd and Sr isotopic variation diagram for Paleocene mafic rocks in the Taihe Basin, Central Jiangxi, Southeast China. DMM, HIMU, EM I and EM II are from Zindler and Hart (1986), MORB in the East Pacific Rise (EPR) is from Wilson (1989), OIB and East Taiwan ophiolite (ETO) N-type basalts field are from Ho et al. (2003). Paleocene mafic rock in Central Jiangxi (this study), $\mathbf{0}$ Paleocene basalts from Sanshui and Heyuan basin, Guangdong (Chung et al., 1997; Zhu and Wang, 1989; Zhu et al., 2004), The fields of Cretaceous basalts and mafic dikes (e.g., Lan et al., 1995; Lapierre et al., 1997; Li and McCulloch, 1998; Chen et al., 2000; Xiong et al., 2003; Ge et al., 2003; Wang et al., 2003; Xie et al., 2006) and Late Cenozoic basalts (e.g., Peng et al., 1986; Tu et al., 1991, 1992; Chung et al., 1995; Zou et al., 2000; Ho et al., $2003)$ in Cathaysia Block are shown for comparison.

\section{DiscuSsion}

Petrogenesis: crustal contamination or source enrichment?

It is important to assess whether continental basaltic magma is affected by en route crustal contamination. The following evidence suggests that the Taihe Basin mafic rocks were little or not affected by crustal contamination (Fig. 6). (1) Large ion lithophile elements (e.g., Ba, Th, $\mathrm{K}, \mathrm{Rb}$ ) in these mafic rocks have lower abundances than those in the upper crust, and high strength field element (HSFE) and heavy rare earth element (HREE) compositions are higher than those in upper crust (Gao et al., 1998) and granulite xenoliths (Yu et al., 2003b) in Southeast China. In addition, these rocks exhibit geochemical characteristics without $\mathrm{Nb}$ and $\mathrm{Ta}$ negative anomalies, similar to those of Late Cenozoic basalts in Southeast China (Ho et al., 2003) and OIB (Sun and McDonough, 1989). (2) $\mathrm{Nb} / \mathrm{U}$ and $\mathrm{Ce} / \mathrm{Pb}$ ratios are $18.0-52.0$ and $9.1-35.8$, respectively, higher than those for continental crust $(\mathrm{Nb} /$ $\mathrm{U}=12.1$ and $\mathrm{Ce} / \mathrm{Pb}=4.1$ ) (Taylor and McLennan, 1995) and the crust in Eastern China $(\mathrm{Nb} / \mathrm{U}=9.6$ and $\mathrm{Ce} / \mathrm{Pb}=$ 4.0) (Gao et al., 1998). In addition, as shown in Fig. 8, $\mathrm{La} / \mathrm{Nb}$ and $\mathrm{Ba} / \mathrm{Nb}$ ratios are $0.64-0.94$ and $5.0-13.0$, respectively, similar to that of Dupal OIB (Jahn et al., 1999). (3) $\mathrm{Pb}$ is significantly enriched in continental crust relative to mantle-derived melts, such as MORB and OIB. Consequently, mantle-derived basalts contaminated from crustal material will significantly enhance the $\mathrm{Pb}$ isotopic 


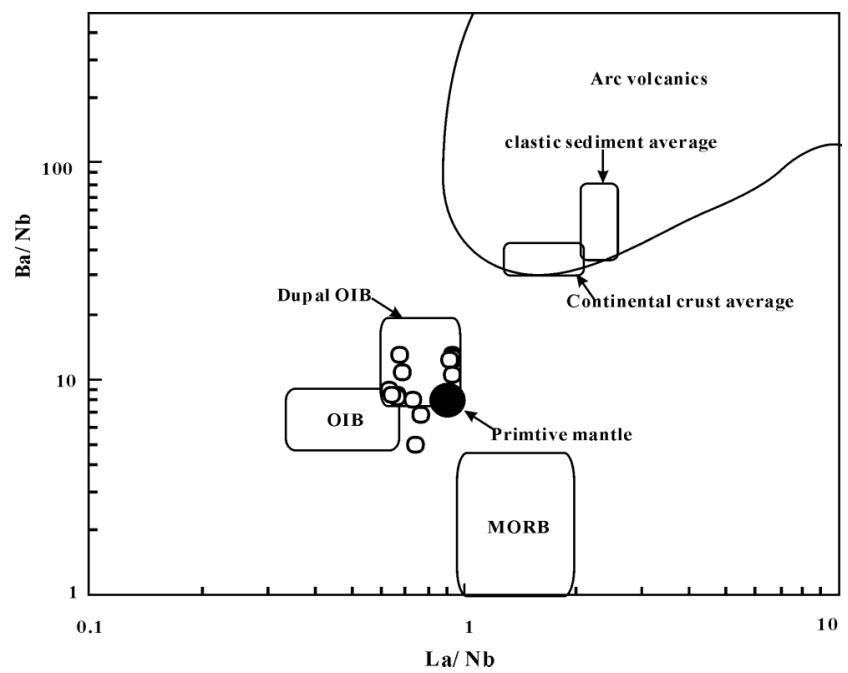

Fig. 8. Diagram of La/Nb versus Ba/Nb ratios for Paleocene mafic rocks in Taihe Basin, Central Jiangxi, Southeast China.
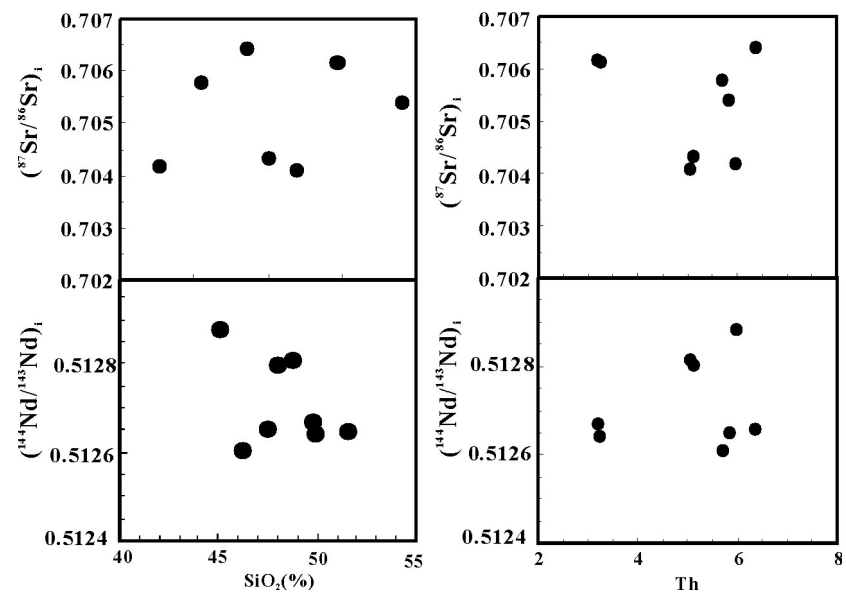

Fig. 9. Initial ${ }^{87} \mathrm{Sr} /{ }^{86} \mathrm{Sr}$ or ${ }^{144} \mathrm{Nd} /{ }^{143} \mathrm{Nd}$ and $\mathrm{SiO}_{2}$ or Th variation diagram for the Taihe Basin Paleocene mafic rocks, Southeast China.

compositions. The average ${ }^{208} \mathrm{~Pb} /{ }^{204} \mathrm{~Pb},{ }^{207} \mathrm{~Pb} /{ }^{204} \mathrm{~Pb}$ and ${ }^{206} \mathrm{~Pb} /{ }^{204} \mathrm{~Pb}$ ratios of $37.849,15.553$ and 18.500 , respectively, for the Taihe Basin mafic rocks are similar to those of least contaminated Late Cenozoic basalts $\left({ }^{208} \mathrm{~Pb} /{ }^{204} \mathrm{~Pb}\right.$ 37.61-39.26; ${ }^{207} \mathrm{~Pb} /{ }^{204} \mathrm{~Pb} 15.45-15.65$ and ${ }^{206} \mathrm{~Pb} /{ }^{204} \mathrm{~Pb}$ 17.65-19.03) in Southeast China (Peng et al., 1986; Tu et al., 1991, 1992; Chung et al., 1995; Zou et al., 2000). (4) $\mathrm{The} \mathrm{SiO}_{2}$ and Th contents of continental crust are generally higher than those of mantle-derived melts, and these rocks if significantly influenced by crustal contamination en route, would exhibit positive correlations among $\mathrm{Sr}$ $\mathrm{Nd}$ isotopic compositions and $\mathrm{SiO}_{2}$ or Th (Piccirillo et al., 1989). However, the studied mafic rocks do not ex-

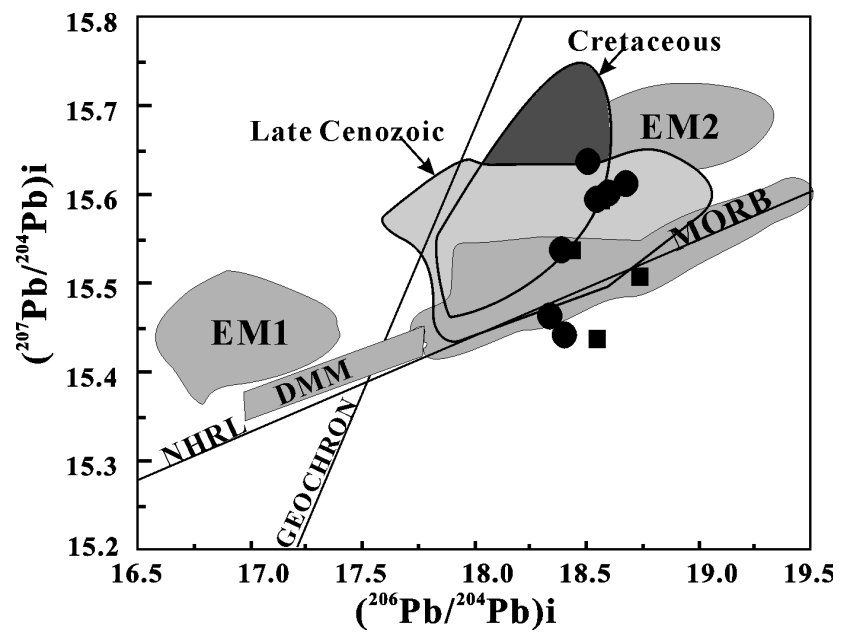

Fig. 10. ${ }^{206} \mathrm{~Pb} /{ }^{204} \mathrm{~Pb}$ and ${ }^{207} \mathrm{~Pb} /{ }^{204} \mathrm{~Pb}$ variation diagram for the Taihe Basin Paleocene mafic rocks, Southeast China. DMM, MORB, EM I, EM II and BSE are from Zindler and Hart (1986).

- Paleocene mafic rocks in Central Jiangxi (this study), Paleocene basalts from Sanshui basin, Guangdong (Zhu and Wang, 1989), The fields of Cretaceous basalts and mafic dikes (e.g., Xie et al., 2001, 2006) and Late Cenozoic basalts (e.g., Peng et al., 1986; Tu et al., 1991, 1992; Chung et al., 1995; Zou et al., 2000) in Cathaysia Block are shown for comparison.

hibit clear correlations between ${ }^{87} \mathrm{Sr} /{ }^{86} \mathrm{Sr}$ or ${ }^{144} \mathrm{Nd} /{ }^{143} \mathrm{Nd}$ and crust-derived elements such as $\mathrm{SiO}_{2}$ and Th (Fig. 9).

From this evidence, we conclude that the Taihe Basin magmas were not significantly affected by crustal contamination. The geochemical characteristics of Paleocene mafic rocks in Southeast China indicate that they inherited mantle characteristics. Consequently, these mafic rocks, with a marked enrichment in LILE and LREE, probably resulted from source enrichment beneath Southeast China.

\section{Magma source}

As discussed above, the Taihe Basin Paleocene mafic rocks exhibit EM 2-like isotopic affinities, having high ${ }^{206} \mathrm{~Pb} /{ }^{204} \mathrm{~Pb}(18.338-18.677)$, high ${ }^{87} \mathrm{Sr} /{ }^{86} \mathrm{Sr}(0.7041-$ $0.7064)$ and moderate ${ }^{143} \mathrm{Nd} /{ }^{144} \mathrm{Nd}\left(\varepsilon_{\mathrm{Nd}}(\mathrm{T})=+0.8-+6.2\right)$ (Zindler and Hart, 1986). The transitional $\mathrm{Pb}$ isotopic compositions between MORB and EM 2 mantle (Fig. 10) suggest mixing between asthenospheric mantle and EM 2 mantle components. These isotopic characteristics can generally be explained as a mixture of asthenosphere and EM 2 mantle, as best illustrated by the ${ }^{143} \mathrm{Nd} /{ }^{144} \mathrm{Nd}$ versus ${ }^{206} \mathrm{~Pb} /{ }^{204} \mathrm{~Pb}$ (Fig. 11) and ${ }^{87} \mathrm{Sr} /{ }^{86} \mathrm{Sr}$ versus ${ }^{206} \mathrm{~Pb} /{ }^{204} \mathrm{~Pb}$ diagrams (Fig. 12). It has been proposed the EM 2 mantle component in Southeast China was derived from continental lithospheric mantle such as Tungchihsu Group II pyroxenite (Ho et al., 2000), and related to the subduc- 


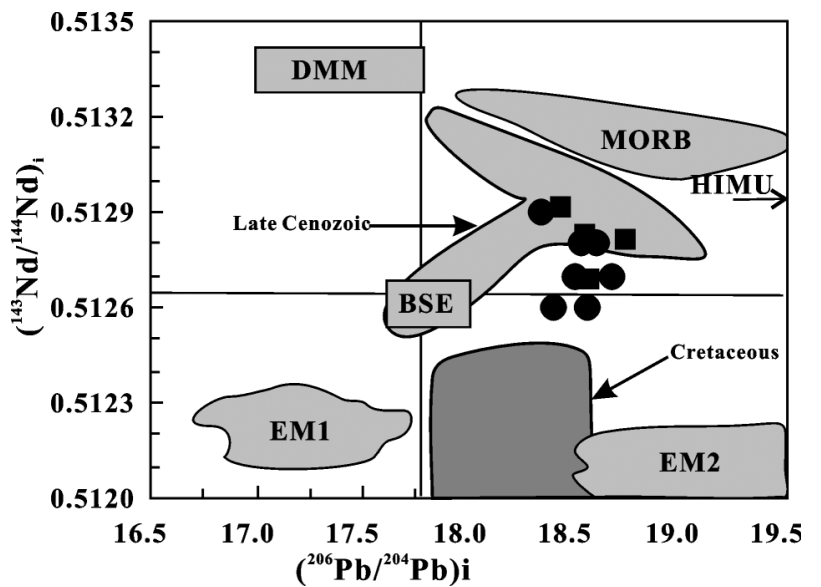

Fig. 11. Initial ${ }^{206} \mathrm{~Pb} /{ }^{204} \mathrm{~Pb}$ and ${ }^{144} \mathrm{Nd} /{ }^{143} \mathrm{Nd}$ variation diagram for Paleocene mafic rocks, Southeast China. Paleocene mafic rocks (this study), $\mathbf{\square}$ Paleocene basalts from Sanshui basin, Guangdong (Zhu and Wang, 1989). Fields of Cretaceous basalts and mafic dikes (e.g., Xie et al., 2001, 2006) and Late Cenozoic basalts (e.g., Peng et al., 1986; Tu et al., 1991, 1992; Chung et al., 1995; Zou et al., 2000) in Cathaysia Block are shown for comparison.

tion of the Paleo-Pacific plate beneath the Eurasian continent in the Late Mesozoic (Chung et al., 1995). Alternatively, these isotopic characteristics may reflect an input from sediments associated with the subduction slab (Zhu and Wang, 1989; Ho et al., 2003). In addition, continental lithospheric mantle reservoirs in extensional terrains may have diverse origins and distinct compositions in southeastern China (Chung et al., 1995). The large variations of $\mathrm{Nd}$ and $\mathrm{Pb}$ isotopic compositions for the Taihe Basin mafic rocks also demonstrate a highly heterogeneous sub-lithospheric mantle beneath this region during the Paleocene. On the basis of the above-mentioned geochemical and isotopic features we argue that the original magma for Central Jiangxi Paleocene mafic rocks was derived from the asthenospheric mantle with a minor involvement of EM 2 lithospheric mantle.

\section{Secular magma sources for basaltic rocks}

Basaltic magmatism is generally the result of mantle partial melting, and magma sources probably change as lithospheric replacement/thinning progresses (e.g., Perry et al., 1988; Daley and DePaolo, 1992). Therefore, it is important to place some temporal constraints on this process by tracking the changes in composition of basaltic magmas through time and relating these changes to the predominant tectonic regime in Southeast China.

In Southeast China Late Cenozoic basalts have OIBlike geochemical characteristics and were dominantly originated by partial melting of depleted asthenospheric mantle (DMM or MORB), with a minor EM 2 lithospheric

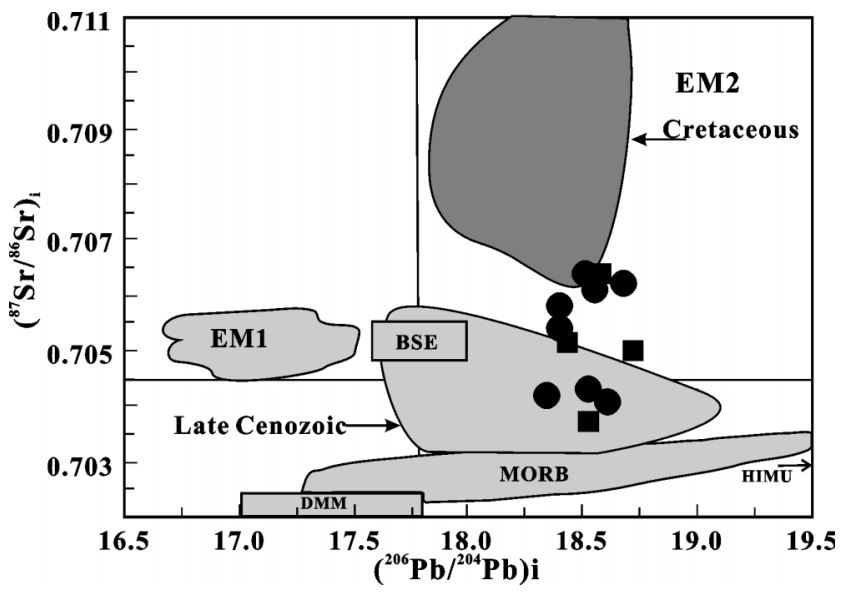

Fig. 12. Initial ${ }^{206} \mathrm{~Pb} /{ }^{204} \mathrm{~Pb}$ and ${ }^{87} \mathrm{Sr} /{ }^{86} \mathrm{Sr}$ variation diagram for Paleocene mafic rocks in Central Jiangxi, Southeast China. - Paleocene maficrocks (this study), $\mathbf{\square}$ Paleocene basalts from Sanshui basin, Guangdong (Zhu and Wang, 1989). The fields of Cretaceous basalts and mafic dikes (e.g., Xie et al., 2001, 2006) and Late Cenozoic basalts (e.g., Peng et al., 1986; Tu et al., 1991, 1992; Chung et al., 1995; Zou et al., 2000) in Cathaysia Block are shown for comparison.

mantle component (Peng et al., 1986; Flower et al., 1992; Tu et al., 1991, 1992; Liu et al., 1994; Qi et al., 1994; Chung et al., 1994, 1995; Zou et al., 2000; Ho et al., 2003). It is also generally accepted that Late Cenozoic volcanism in Southeast China was related to lithospheric extension due to asthenospheric upwelling (Chung et al., 1994, 1995; Qi et al., 1994; Zou et al., 2000; Ho et al., 2003). On the other hand, Cretaceous basaltic magmatism exhibits enriched geochemical and isotopic features, similar to those of continental arc basalts, indicating that they were derived from highly heterogeneous EM 2 lithospheric mantle with a minor involvement of asthenospheric mantle (Lan et al., 1995; Li and McCulloch, 1998; Xie et al., 2001; Xiong et al., 2003; Ge et al., 2003; Wang et al., 2003; Xie et al., 2006), suggesting contamination associated with the subduction of Paleo-Pacific plate (Jahn et al., 1990; Northrup et al., 1995; Lapierre et al., 1997). By contrast, the Paleocene mafic rocks show transitional geochemical features between Cretaceous and Late Cenozoic basaltic rocks in Southeast China. This observation is based on the following evidence:

(1) Most of Cretaceous basaltic rocks belong to the sub-alkaline series (Li and McCulloch, 1998; Zhao et al., 2004; Xie et al., 2006), whereas Late Cenozoic basaltic rocks have compositions ranging from tholeiitic to a strongly alkali affinity (Ho et al., 2003) (Fig. 3).

(2) MORB-normalized incompatible trace elements patterns for Cretaceous basaltic rocks are similar to those of continental arc basalts with $\mathrm{Nb}$ and Ta negative anoma- 
lies (Lan et al., 1995; Lapierre et al., 1997; Xiong et al., 2003; Ge et al., 2003; Yu et al., 2003b; Zhao et al., 2004; Xie et al., 2006), whereas Late Cenozoic basalts display OIB-like geochemical characteristics with well defined $\mathrm{Nb}$ and Ta positive anomalies (Peng et al., 1986; Flower et al., 1992; Tu et al., 1992; Qi et al., 1994; Liu et al., 1994; Chung et al., 1994, 1995; Zou et al., 2000; Ho et al., 2003). Paleocene mafic rocks in this study show transitional geochemical characteristics between Cretaceous and Late Cenozoic basaltic rocks, and are similar to Late Cenozoic basalts (Fig. 6).

(3) Although with similar $\mathrm{Pb}$ isotopic compositions (Fig. 10), Cretaceous, Paleocene and Late Cenozoic basaltic magmastism exhibit significantly different $\mathrm{Sr}-\mathrm{Nd}$ isotopic data. Cretaceous basaltic rocks have high initial Sr ratios $\left({ }^{87} \mathrm{Sr} /{ }^{86} \mathrm{Sr}_{\mathrm{i}}=0.7051-0.7145\right)$ and low initial $\mathrm{Nd}$ ratios $\left({ }^{143} \mathrm{Nd} /{ }^{144} \mathrm{Nd}_{\mathrm{i}}=0.5119-0.5128\right)$ (Lan et al., 1995; Lapierre et al., 1997; Li and McCulloch, 1998; Xie et al., 2001, 2006; Xiong et al., 2003; Ge et al., 2003; Wang et al., 2003). Late Cenozoic basalts have low initial ${ }^{87} \mathrm{Sr} /$ ${ }^{86} \mathrm{Sr}$ ratios $(0.7032-0.7066)$ and high initial ${ }^{143} \mathrm{Nd} /{ }^{144} \mathrm{Nd}$ ratios (0.5126-0.5129) (Peng et al., 1986; Tu et al., 1991, 1992; Chung et al., 1994, 1995; Liu et al., 1994; Zou et al., 2000; Ho et al., 2003). Paleocene mafic rocks in this study plot within fields that are transitional between Cretaceous and Late Cenozoic basaltic rocks on the ${ }^{87} \mathrm{Sr} /{ }^{86} \mathrm{Sr}$ vs. ${ }^{143} \mathrm{Nd} /{ }^{144} \mathrm{Nd},{ }^{87} \mathrm{Sr} /{ }^{86} \mathrm{Sr}$ vs. ${ }^{206} \mathrm{~Pb} /{ }^{204} \mathrm{~Pb}$ and ${ }^{143} \mathrm{Nd} /{ }^{144} \mathrm{Nd}$ vs. ${ }^{206} \mathrm{~Pb} /{ }^{204} \mathrm{~Pb}$ diagrams (Figs. $7,11,12$ ).

From this evidence, we conclude that a secular magma source responsible for both Cretaceous and Cenozoic basaltic rocks in Southeast China changed from the subduction-modified lithospheric mantle in the earlier stages to asthenospheric mantle in the later stages, reflecting a change from a continental arc setting to an intra-plate extensional regime (Chung et al., 1997; Yu et al., 2003b, this study).

\section{Implications for lithospheric replacement}

$\mathrm{La} / \mathrm{Nb},{ }^{87} \mathrm{Sr} /{ }^{86} \mathrm{Sr}$ and ${ }^{143} \mathrm{Nd} /{ }^{144} \mathrm{Nd}$ are powerful monitors to distinguish lithospheric mantle from asthenosphere sources for extension-related magmatism (Fitton et al., 1988; DePaolo and Daley, 2000). For example, Fitton et al. (1988) postulated that basalts with $\mathrm{La} / \mathrm{Nb}$ ratios $<1.5$ from the Basin and Range Province (USA) were originated from melting of an asthenospheric source, whereas lavas with $\mathrm{La} / \mathrm{Nb}$ ratios of $>1.5$ from the Sierra Nevada were derived from enriched lithospheric mantle. DePaolo and Daley (2000) proposed that the depth of the lithosphere-asthenosphere boundary can be inferred from the $\varepsilon_{\mathrm{Nd}},{ }^{87} \mathrm{Sr} /{ }^{86} \mathrm{Sr}$ and $\mathrm{La} / \mathrm{Nb}$ values of the lavas as a function of age, and an estimate of the depth of the magma source can be obtained on the basis of silica saturation. As shown in Fig. 13, Cretaceous basaltic rocks have higher ${ }^{87} \mathrm{Sr} /{ }^{86} \mathrm{Sr}$ and lower ${ }^{143} \mathrm{Nd} /{ }^{144} \mathrm{Nd}$ and $\mathrm{La} / \mathrm{Nb}(0.04-$
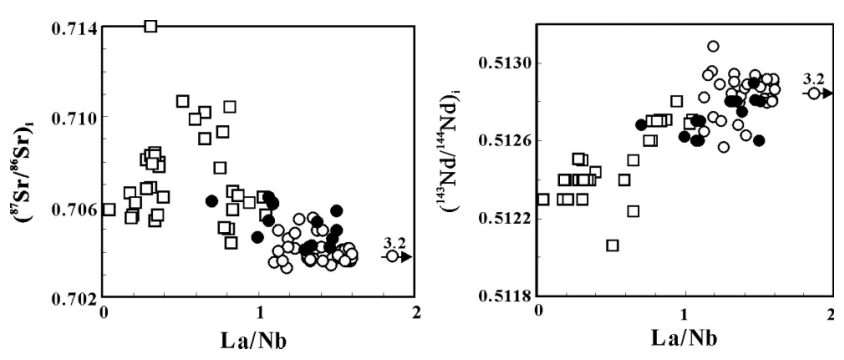

Fig. 13. Initial ${ }^{87} \mathrm{Sr} /{ }^{86} \mathrm{Sr}$ or ${ }^{144} \mathrm{Nd} /{ }^{143} \mathrm{Nd}$ versus $\mathrm{La} / \mathrm{Nb}$ variation diagram for Paleocene mafic rocks in Central Jiangxi, Southeast China. The ratios of Cretaceous and Late Cenozoic basaltic rocks are shown for comparison. Paleocene basaltic rocks in Southeast China (Chung et al., 1997, this study), $\bigcirc$ Late Cenozoic basalts in Cathaysia Block (e.g., Chung et al., 1995; Zou et al., 2000; Ho et al., 2003), $\square$ Cretaceous basalts and mafic rocks in Cathaysia Block (e.g., Lan et al., 1995; Lapierre et al., 1997; Li and McCulloch, 1998; Xiong et al., 2003; Ge et al., 2003).

1.0) ratios than Late Cenozoic basalts with $\mathrm{La} / \mathrm{Nb}$ ranging from (1.1-3.2), whereas the $\varepsilon_{\mathrm{Nd}}$, and $\mathrm{La} / \mathrm{Nb}$ values for Cretaceous and Cenozoic basaltic rocks increase and the ${ }^{87} \mathrm{Sr} /{ }^{86} \mathrm{Sr}$ ratios decrease with time. This trend suggests that secular magma source responsible for basaltic rocks in Southeast China had been gradually evolved from enriched lithospheric mantle in the Cretaceous to depleted asthenospheric mantle in the Late Cenozoic.

This temporal shift from a lithospheric to asthenospheric magma source beneath Southeast China is similar to that seen in the Basin and Range Province and Northeast Japan where the involvement of subcontinental lithosphere for magma source significantly decreases with time as lithospheric extension and thinning increase (Nohda et al., 1988; Tatsumi et al., 1988; Fitton et al., 1991; DePaolo and Daley, 2000). Therefore, we believe that the involvement of asthenospheric mantle beneath Southeast China gradually increased with time, and the temporal shift from a lithospheric to asthenospheric magma source was probably related to progressive lithospheric extension and thinning, as well as asthenospheric upwelling in this region (Chung et al., 1997; Xu et al., 2000; Wang and O'Reilly, 2003). Many studies indicated that dry asthenosphere could melt only when the lithosphere is sufficiently thinned $(<60 \mathrm{~km})(\mathrm{Xu}$ et al., 2004). Consequently, the lithospheric mantle was probably significantly thinned and replaced at the beginning of the Paleocene in Southeast China; otherwise Paleocene mafic rocks in this study would not exhibit OIB-like geochemical affinities, distinct from Cretaceous basaltic rocks. Lithospheric thinning and replacement had finished and decompression melting of the upwelling asthenosphere had taken place during the Paleocene pe- 
riod in Southeast China. Paleocene mafic rocks in this study represent the surface manifestation of this event $(\mathrm{Xu}$ et al., 2004).

The integration of available geological, geochemical and geophysical data of Late Mesozoic igneous rocks indicates that the angle of Pacific plate subducting slab beneath Southeastern China increased from a very low angle to a middle angle from 180 to $80 \mathrm{Ma}$, and that mantle input may have played an important role in the formation of extensive Mesozoic magmastism (Zhou and Li, 2000). Perhaps, this significant change from a continental arc setting to an intra-plate extensional regime reflected the eastward migration of the subduction zone of the $\mathrm{Pa}$ cific Plate and/or increase of the subduction angle beneath Southeast China (Yu et al., 2003b). An analysis of the motion of the Pacific plate relative to the Eurasian continent suggests that the rate of the Pacific-Eurasia convergence was $120-140 \mathrm{~mm} / \mathrm{yr}$ in the Late Cretaceous and declined substantially during the Paleocene period and reached a minimum in the Eocene time of about 30$40 \mathrm{~mm} / \mathrm{yr}$, which correlates with widespread extension along the eastern margin of Eurasia in the Cenozoic (Northrup et al., 1995).

As discussed above, secular geochemical and isotopic variation for Cretaceous and Cenozoic basaltic rocks in Southeast China is similar to that seen in Northeast Japan where the $\mathrm{Nd}$ and $\mathrm{Sr}$ isotopic characteristics of Late Tertiary basalts show a trend from enriched signature in the pre-opening stage of Japan Sea to a depleted one in the post-opening (Nohda et al., 1988; Tatsumi et al., 1988). This temporal shift from a lithospheric to asthenospheric magma source may be associated with back-arc rifting and trench retreat and the steepening of the subducted oceanic lithosphere, probably induced by the asthenosphere injection into the mantle wedge (Nohda et al., 1988; Tatsumi and Kimura, 1991). Consequently, we suggest that lithospheric replacement may have been related to lithosphere extension and thinning, and asthenospheric upwelling during the Paleocene, which resulted from the subduction roll-back and/or steepening of the Pacific plate due to injection of asthenospheric material into the mantle wedge beneath Southeast China.

\section{CONCLUSIONS}

On the basis of the age data integrated with $\mathrm{Sr}-\mathrm{Nd}-\mathrm{Pb}$ isotope systematics presented in this contribution, we conclude that:

(1) K-Ar dating and field evidence show that mafic rocks in the Taihe Basin in central Jiangxi, SE China were emplaced in the Paleocene.

(2) Geochemical and isotopic evidence suggests that these mafic rocks are dominantly originated from asthenospheric mantle (DMM or MORB) with a minor involvement of EM 2 lithospheric mantle.

(3) Paleocene mafic rocks exhibit a transitional geochemical characteristics between Cretaceous and Late Cenozoic basaltic rocks, indicating that the involvement of asthenospheric mantle beneath Southeast China gradually increase with time.

(4) The lithospheric replacement was associated with lithospheric extension and thinning, with decompression melting of the upwelling asthenosphere having taken place in the Paleocene. This, in turn, was probably related to subduction roll-back and/or steepening of Paleo-Pacific plate due to injection of asthenospheric material into the mantle wedge beneath Southeast China.

Acknowledgments-This research was supported jointly by National Science Foundation of China (Grant No. 40402011 and 40434011), and the Chinese Academy of Sciences (KZCX3SW-125), and China Postdoctoral Science Foundation, and Key Laboratory of Geological Processes and Mineral Resources, China University of Geosciences (GPM40504) and State Key Laboratory of Ore Deposit Geochemistry, Institute of Geochemistry, Chinese Academy of Sciences China (200402). The authors were grateful to senior engineer Chun-Gen Liu for field trips. We thank Profs. Yue-Jun Wang, Mei-Fu Zhou, Hong$\mathrm{Fu}$ Zhang and Li-Shen Zhang for their thoughtful comments that significantly improve the content and presentation of the manuscript. Franco Pirajno publishes with the permission of the Director of the Geological Survey of Western Australia.

\section{REFERENCES}

Boynton, W. V. (1984) Geochemistry of the rare earth elements: meteorite studies. Rare Earth Element Geochemistry (Henderson, P., ed.), 63-114, Elsevier.

Bureau of Geology and Mineral Resources of JiangXi province (BGMRJX) (1984) Regional Geology of Jiangxi Province. Geological Publishing House, Beijing, 921 pp. (in Chinese with English abstract).

Bureau of Geology and Mineral Resources of JiangXi province (BGMRJX) (1995a) Description of 1:50000 Futian geological maps (in Chinese) (unpublished).

Bureau of Geology and Mineral Resources of JiangXi province (BGMRJX) (1995b) Description of 1:50000 Taihe geological maps (in Chinese) (unpublished).

Bureau of Geology and Mineral Resources of JiangXi province (BGMRJX) (1995c) Description of 1:50000 Yongheyu geological maps (in Chinese) (unpublished).

Bureau of Geology and Mineral Resources of JiangXi province (BGMRJX) (1995d) Description of 1:50000 Jian geological maps (in Chinese) (unpublished).

Bureau of Geology and Mineral Resources of JiangXi province (BGMRJX) (1995e) Description of 1:50000 Baijia geological maps (in Chinese) (unpublished).

Chen, C.-H., Lin, W., Lu, H.-Y., Lee, C.-Y., Tien, J.-L. and Lai, Y.-H. (2000) Cretaceous fractionated I-type granitoids and metaluminous A-type granites in SE China: the late Yanshanian post-orogenic magmatsim: Transactions of the 
Royal Society of Edinburgh. Earth Sciences 91, 195-205.

Chen, J. F. and Jahn, B. M. (1998) Crustal evolution of southeastern China, $\mathrm{Nd}$ and $\mathrm{Sr}$ isotopic evidence. Tectonophysics 284, 101-133.

Chung, S. L., Sun, S.-s., Tu, K., Chen, C.-H. and Lee, C. Y. (1994) Late Cenozoic basaltic volcanism around the Taiwan Strait, SE China: Product of lithosphere-asthenosphere interaction during continental extension. Chem. Geol. 112, $1-20$.

Chung, S. L., Jahn, B. M., Chen, S. J., Lee, T. and Chen, C.-H. (1995) Miocene basalts in northwestern Taiwan, Evidence for EM-type sources in the continental lithosphere. Geochim. Cosmichim. Acta 59, 549-555.

Chung, S. L., Cheng, H., Jahn, B. M., O'Reilly, S. Y. and Zhu, B.-Q. (1997) Major and trace, and Sr-Nd isotope constrains on the origin of Paleogene volcanism in South China prior to the South China Sea opening. Lithos 40, 203-220.

Cong, B. L., Guo, J. H. and Liu, W. J. (2001) A possible relict mantle wedge: geochemical evidence from Paleogene volcanism in North China. Chinese Science Bulletin 46, 1917-1922.

Daley, E. E. and DePaolo, D. J. (1992) Isotopic evidence for lithospheric thinning during extension: southeastern Great Basin. Geology 20, 104-108.

DePaolo, D. J. and Daley, E. E. (2000) Neodymium isotopes in basalts of the southwest basin and range and lithospheric thinning during continental extension. Chem. Geol. 169, $157-185$.

Fan, Q. C. and Hooper, P. R. (1991) The Cenozoic basaltic rocks of eastern China, petrology and chemical composition. $J$. Petrol. 32, 765-810.

Fitton, J. G., James, D., Kempton, P. D., Ormerod, D. S. and Leeman, W. P. (1988) The role of lithospheric mantle in the generation of late Cenozoic basic magmas in the western United States. J. Petrol. (Lithosphere Issue), 331-349.

Fitton, J. G., James, D. and Leeman, W. P. (1991) Basic magmatism associated with Late Cenozoic extension in the western United States, compositional variations in space and time. J. Geophys. Res. 96, 13693-13711.

Flower, M. F. J., Zhang, M., Chen, C.-Y., Tu, K. and Xie, G. H. (1992) Magmatism in the South China Basin: 2. Post-spreading Quaternary basalts from Hainan Island, South China. Chem. Geol. 97, 65-87.

Gao, S., Luo, T.-C., Zhang, B.-R., Zhang, H.-F., Han, Y.-W., Zhao, Z.-D. and Hu, Y.-K. (1998) Chemical composition of the continental crust as revealed by studies in East China. Geochim. Cosmichim. Acta 62, 1959-1975.

Ge, X. Y., Li, X. H. and Zhou, H. W. (2003) Chronology,element geochemistry and $\mathrm{Sr}-\mathrm{Nd}$ isotope of later Cretaceous mafic dikes swarms from South Hainan. Geochimica 32, 11-19 (in Chinese with English abstract).

Gilder, S. A., Keller, G. R., Luo, M. and Goodell, P. C. (1991) Timing and spatial distribution of rifting in China. Tectonophysics 197, 225-243.

Ho, K. S., Chen, J. C., Smith, A. D. and Juang, W. S. (2000) Petrogenesis of two groups of pyroxenite from Tungchihsu, Penghu Islands, Taiwan Strait, implications for mantle metasomatism beneath SE China. Chem. Geol. 167, 355372.
Ho, K. S., Chen, J. C., Lo, C. H. and Zhao, H.-L. (2003) ${ }^{40}$ Ar${ }^{39} \mathrm{Ar}$ dating and geochemical characteristics of late Cenozoic basaltic rocks from the Zhejiang-Fujian region, SE China, eruption ages, magma evolution and petrogenesis. Chem. Geol. 197, 287-318.

$\mathrm{Hu}$, S. B., He, L. J. and Wang, J. Y. (2000) Heat flow in the continental area of China, a new data set. Earth Planet. Sci. Lett. 179, 407-419.

Irvine, T. N. and Baragar, W. R. A. (1971) A guide to the chemical classification of the common volcanic rocks. Canadian Journal of Earth Science 8, 523-548.

Jahn, B. M., Zhou, X. H. and Li, J. L. (1990) Formation and tectonic evolution of southeastern China and Taiwan: isotopic and geochemical constraints. Tectonophysics 183, $145-160$.

Jahn, B. M., Wu, F., Lo, C. H. and Tsai, C.-H. (1999) Curstmantle interaction induced by deep subduction of the continental crust: geochemical and $\mathrm{Sr}-\mathrm{Nd}$ isotopic evidence from post-collisional mafic-ultramafic intrusions of the northern Dabie complex, Central China. Chem. Geol. 157, 119-146.

Lan, C. Y., Chung, S. L., Mertzman, S. A. and Chen, C. H. (1995) Mafic dikes from Chinmen and Liehyu islands off SE China, petrochemical characteristics and tectonic implication. Journal of Geological Society of China 38, 183214.

Lapierre, H., Jahn, B. M., Charver, J. and Yu, Y. W. (1997) Mesozoic felsic arc magmastism and continental olivine tholeiites in Zhejing province and their relationship with the tectonic activity in southeastern China. Tectonophysics 274, 321-338.

$\mathrm{Li}, \mathrm{X} . \mathrm{-H}$. (1999) U-Pb zircon ages of granites from the southern margin of the Yangtze Block: timing of Neoproterozoic Jinning: Orogeny in SE China and implications for Rodinia Assembly. Precambrian Research 97, 43-57.

Li, X.-H. and McCulloch, M. T. (1998) Geochemical characteristics of Cretaceous mafic dikes from northern Guangdong, SE China, age, origin and tectonic significance. Mantle Dynamics and Plate Interaction in East Asia (Flower, M. F. J., Chung, S.-L., Lo, C.-H. and Lee, T. Y. eds.), Washington, D.C., AGU, Geodynamics 27, 405-419.

Li, X. H., Chen, Z. G., Liu, D. Y. and Li, W. X. (2003) Jurassic gabbro-granite-syenite suites from Southern Jiangxi Province, SE China: age, origin, and tectonic significance. Int. Geol. Rev. 45, 898-921.

Liu, B. X. and Li, Y. M. (2001). Chief progress in 1:50000 regional geological surveys during the 9th five-year-plan in Jiangxi. Jiangxi Geology 15, 225-230 (in Chinese with English abstract).

Liu, C. Q., Masuda, A. and Xie, G. H. (1994) Major- and traceelement compositions of Cenozoic basalts in eastern China, petrogenesis and mantle source. Chem. Geol. 114, 19-42.

McCulloch, M. T. and Gamble, T. A. (1991) Geochemical and geodynamical constraints on subduction zone magmatism. Earth Planet. Sci. Lett. 102, 358-374.

Nohda, S., Tatsumi, Y., Otofuji, Y., Matsuda, T. and Ishizaka, K. (1988) Asthenospheric injection and back-arc opening, isotopic evidence from the northeast Japan. Chem. Geol. 68, 317-327. 
Northrup, C. J., Royden, L. H. and Burchfiel, B. C. (1995) Motion of the Pacific plate relative to Eurasia and its potential relation to Cenozoic extension along the eastern margin of Eurasia. Geology 23, 719-722.

Peng, T.-P., Wang, Y.-J., Jiang, Z.-M., Yu, X.-B. and Peng, B.X. (2004) ${ }^{40} \mathrm{Ar} /{ }^{39} \mathrm{Ar}$ geochronology and geochemistry of Cretaceous basaltic rocks for the central and northwestern Jiangxi Province. Geochemica 33, 447-458 (in Chinese with English abstract).

Peng, Z. C., Zartman, R. E., Futa, K. and Chen, D. G. (1986) $\mathrm{Pb}, \mathrm{Sr}$ and $\mathrm{Nd}$ isotopic systematics and chemical characteristics of Cenozoic basalts, eastern China. Chem. Geol. 59, 3-33.

Perry, F. V., Baldridge, W. S. and DePallo, D. J. (1988) Chemical and isotopic evidence for lithospheric thinning beneath the Rio Grande rift. Nature 332, 432-434.

Piccrillo, E. E., Civetta, L., Petrini, R., Longinelli, A., Bellieni, G., Comin-Chiaramontl, P., Marques, L. S. and Melfi, A. J. (1989) Regional variations within the Paraná flood basalts (southern Brazil), evidence for subcontinental mantle heterogeneity and crust contamination. Chem. Geol. 75, 103122.

Qi, L. and Grégoire, D. C. (2000) Determination of trace elements in twenty-six Chinese geochemistry reference materials by inductively coupled plasma-mass spectrometry. Geostandard Newsletter 24, 51-63.

Qi, Q., Taylor, L. A. and Zhou, X. (1994) Geochemistry and petrogenesis of three series of Cenozoic basalts from southeastern China. Int. Geol. Rev. 36, 435-451.

Rollinson, H. R. (1993) Using Geochemical Data: Evaluation, Presentation, Interpretation. Longman Scientific and Technical, New York, 352 pp.

Shen, W. Z., Zhao, L. Z., Zhao, M., Kong, Q. Y. and Cai, Y. F. (2002) Study on Nd-Sr isotopic compositions of Tertiary basalts from Jiyang depressional basin. Acta Petrologica Scinica 18, 47-58 (in Chinese with English abstract).

Sun, S. S. and McDonough, W. (1989) Chemical and isotopic systematic basalt, Implication for mantle composition and processes. Magmatism in the Ocean Basins (Saunders, A. D. and Norry, M. J., eds.), Geological Society Special Publication 42, 313-345.

Tanaka, T., Togashi, S., Kamioka, H., Amakawa, H., Kagami, H., Hamamoto, T., Yuhara, M., Orihashi, Y., Yoneda, S., Shimizu, H., Kunimaru, T., Takahashi, K., Yanagi, T., Nakano, T., Fujimaki, H., Shinjo, R., Asahara, Y., Tanimizu, M. and Dragusanu, C. (2000). JNdi-1, a neodymium isotopic reference in consistency with LaJolla neodymium. Chem. Geol. 168, 279-281.

Tatsumi, Y. and Kimura, N. (1991) Backarc extension versus continental breakup: petrological aspects for active rifting. Tectonophysics 197, 127-137.

Tatsumi, Y., Nohda, S. and Ishizaka, K. (1988) Secular variation of magma source compositions beneath the northeast Japan arc. Chem. Geol. 68, 309-316.

Taylor, S. R. and McLennan, S. M. (1995) The geochemical evolution of the continental crust. Rev. Geophys. 33, 241265.

Tu, K., Flower, M. F. J., Carlson, R. W., Zhang, M. and Xie, G. H. (1991) $\mathrm{Sr}, \mathrm{Nd}$, and $\mathrm{Pb}$ isotopic compositions of Hainan basalts (South China), Implications for a subcontinental lithosphere Dupal source. Geology 19, 567-569.

Tu, K., Flower, M. F. J., Carlson, R. W., Xie, G. H., Chen, C. Y. and Zhang, M. (1992) Magmatism in the South China Basin. 1. Isotopic and trace element evidence for an endogenous Dupal mantle component. Chem. Geol. 97, 47-63.

Wang, K. L. and O'Reilly, S. Y. (2003) Proterozoic mantle lithosphere beneath the extended margin of the South China Block: In situ Re-Os evidence. Geology 31, 709-712.

Wang, Y., Guang, T. Y. and Huang, G. F. (2002) Isotope chronological studies of late Yanshanian volcanic rocks in northeast Jiangxi Province. Acta Geoscientia Sinica 23, 233-236 (in Chinese with English abstract).

Wang, Y. J., Fan, W. M., Guo, F., Peng, T. P. and Li, C. W. (2003) Geochemistry of Mesozoic mafic rocks adjacent to the Chenzhou-Linwu fault, South China: implications for the lithospheric boundary between the Yangtze and Cathaysia Blocks. Int. Geol. Rev. 45, 263-286.

Wang, Y.-J., Liao, C.-L., Fan, W. M. and Guo, F. (2004) Early Mesozoic OIB-type alkaline basalt in central Jiangxi province and its tectonics implications. Geochimica 33, 109117 (in Chinese with English abstract).

Wang, Y. J., Fan, W. M., Peng, T. P. and Guo, F. (2005) Elemental and $\mathrm{Sr}-\mathrm{Nd}$ isotopic systematics of the early Mesozoic volcanic sequence in southern Jiangxi Province, South China: petrogenesis and tectonic implications. International Journal of Earth Sciences 94, 53-65.

Wilson, M. (1989) Igneous Prtrogenesis. Unwin Hyman, London, $374 \mathrm{pp}$.

Xie, G. Q., Mao, J. W., Hu, R. Z., Li, R. L. and Cao, J. J. (2005a) Secular evolution of Cretaceous-Cenozoic lithosphere mantle beneath the Cathaysia Block: geochemical evidence for temporal variations in basaltic magmatism. Geochim. Cosmichim. Acta 69 (Supp.), A109.

Xie, G. Q., Mao, J. W., Hu, R. Z., Li, R. L., Jiang, G. H., Cao, J. J. and Zhao, J. H. (2005b) Jurassic intra-plate basaltic magmatism in southeast China: evidence from geological and geochemical characteristics of the chebu gabbroite in southern Jiangxi province. Acta Geologica Sinica (English edition) 79, 662-672.

Xie, G. Q., Hu, R. Z., Mao, J. W., Pirajno, F., Li, R. L., Cao, J. J., Jiang, G. H. and Zhao, J. H. (2006) K-Ar dating, geochemical and $\mathrm{Sr}-\mathrm{Nd}-\mathrm{Pb}$ isotopic systematics of late Mesozoic mafic dikes, southern Jiangxi Province, SE China: petrogenesis and tectonic implications. Int. Geol. Rev. (in press).

Xie, X., Xu, X. S., Zou, H. B. and Xing, G. F. (2001) Trace element and $\mathrm{Nd}-\mathrm{Sr}-\mathrm{Pb}$ isotope studies of Mesozoic and Cenozoic basalts in coastal area of SE China. Acta Petrolgoical Sinica 17, 617-628 (in Chinese with English abstract).

Xing, G. F., Yang, Z. L., Chen, R., Shen, J. L., Wei, N. Y. and Zhou, Y. Z. (2004) Three stages of Mesozoic bimodal igneous rocks and their tectonic implications on the continental margin of southeastern China. Acta Geologica Sinica (English edition) 78, 27-39.

Xiong, X.-L., Li, X.-H., Xu, J.-F., Li, W.-X., Zhao, Z.-H., Wang, Q. and Chen, X.-M. (2003) Extremely high-Na adakite-like magmas derived from alkali-rich basaltic underplate, the 
late Cretaceous Zhangtang andesites in the Huichang basin, SE China. Geochem. J. 37, 233-252.

Xu, X. S. and Xie, X. (2005) Late Mesozoic-Cenozoic Basaltic Rocks and Crust-Mantle Interaction, SE China. Geological Journal of China Universities 11, 318-314 (in Chinese with English abstract).

Xu, X. S., O'Reilly, S. Y., Griffin, W. L. and Zhou, X. M. (2000) Genesis of young lithospheric mantle in SE China. J. Petrol. 41, 111-148.

Xu, X. S., O'Reilly, S. Y., Griffin, W. L. and Zhou, X. M. (2003) Enrichment of upper mantle peridotite, petrological, trace element and isotopic evidence in xenoliths from SE China. Chem. Geol. 198, 163-188.

Xu, Y. G., Sun, M., Yan, W., Liu, Y., Huang, X. L. and Chen, X. M. (2002) Xenolith evidence for polybaric melting and stratification of the upper mantle beneath South China. Journal of Asian Earth Sciences 20, 937-954.

Xu, Y.-G., Huang, X. L., Ma, J. L., Wang, Y. B., Iizuka, Y., Xu, J. F., Wang, Q. and Wu, X. Y. (2004) Crustal-mantle interaction during the thermo-tectonic reactivation of the North China Craton: SHRIMP zircon U-Pb age, petrology and geochemistry of Mesozoic plutons in western Shandong. Contrib. Mineral. Petrol. 147, 750-767.

Yang, W. (2003) Flat mantle reflectors in Eastern China, possible evidence of lithospheric thinning. Tectonophysics $\mathbf{3 6 9}$, 219-230.

Yang, Z. L., Tao, K. Y., Shen, W. Z., Wang, L. B. and Yang, Z. Z. (1998) Geochemistry and source characters of the concealed Eogene basalts in north Jiangsu basin. Acta Petrologica Scinica 14, 332-342 (in Chinese with English abstract).

Yu, J. H., O'Reilly, S. Y., Griffin, W. L., Xu, X., Zhang, M. and Zhou, X. (2003a) The thermal state and composition of the lithospheric mantle beneath the Leizhou Peninsula, South China. J. Volcanol. Geotherm. Res. 122, 165-189.

Yu, J. H., Xu, X. S., O'Reilly, S. Y., Griffin, W. L. and Zhang, M. (2003b) Granulite xenoliths from Cenozoic Basalts in SE China provide geochemical fingerprints to distinguish lower crust terrenes from the North and South China tectonic Blocks. Lithos 67, 77-102.

Yu, X. Q., Shu, L. S., Deng, F. H., Wang, B. and Zu, F. P. (2005) Geochemical features and tectonic significance of the alkali basalts from Ji'an-Taihe basin, Jiangxi Province. Geoscience 19, 133-141 (in Chinese with English abstract).

Yu, Y. W., Zhou, T. X. and Chen, J. F. (1993) The Characteris- tics and origin of the Xuantandi bimodal volcanic rocks of the late stage of early Cretaceous, Zhejiang. Journal of Nanjing University (Earth Sciences) 5, 420- 429 (in Chinese with English abstract).

Zhang, Z., Badal, J., Li. Y., Chen, Y., Yang, L. and Teng, J. (2005) Crust-upper mantle seismic velocity structure across Southeastern China. Tectonophysics 395, 137-157.

Zhao, J. H., Hu, R. Z. and Liu, S. (2004) Geochemistry, petrogenesis, and tectonic significance of Mesozoic mafic dikes, Southeastern China. Int. Geol. Rev. 46, 542-557.

Zheng, J. P., O’Reilly, S. Y., Griffin, W. L., Zhang, M., Lu, F. X. and Liu, G. L. (2004) Nature and evolution of MesozoicCenozoic lithospheric mantle beneath the Cathaysia Block, SE China. Lithos 74, 41-65.

Zheng, W. and Zhang, F. Y. (1996) Geological characteristics of alkaline series basic igneous rock in the Ji-Tai basin and its tectonic significance. Geological Science and Technology of Jiangxi 23 (Supp.), 57-61.

Zhou, J. Y., Cui, B. F., Fang, W. B. and Chen, S. Z. (1998) The bimodal volcanic rocks in the Huichang basin,Jiangxi Province and their tectonic setting. Volcanology and Mineral Resoureces 19, 12-23 (in Chinese with English abstract).

Zhou, T. X. Chen, J. F. and Chen Z. Q. (1993) Isotope Geochemistry of Petrogenesis and Metallogenies and CrustMantle Evolution. Seismic Press, Beijing, 244 pp. (in Chinese).

Zhou, X. M. and Li, W. X. (2000) Origin of late Mesozoic igneous rock in SE China, implications for lithosphere subduction and underplating of mafic magmas. Tectonophysics 326, 269-287.

Zhu, B.-Q. and Wang, H. F. (1989) Geochronology of and Nd$\mathrm{Sr}-\mathrm{Pb}$ isotopic evidences for mantle source in the ancient subduction zone beneath Sanshui Basin, Guangdong Province, China. Chinese Journal of Geochemistry 8, 65-71.

Zhu, B. Q., Wang, H. F., Chen, Y. W., Chang, X.-Y., Hu, Y.-G. and Cie, J. (2004) Geochronogical and geochemical constraint on the Cenozoic extension of Cathaysia lithosphere and tectonic evolution of the border sea basins in East Asian. Journal of Asian Earth Science 24, 163-175.

Zindler, A. and Hart, S. R. (1986) Chemical geodynamics. Annual of Review Earth and Planetary 14, 493-571.

Zou, H. B., Zindler, A., Xu, X. S. and Qi, Q. (2000) Major, trace element, and $\mathrm{Nd}, \mathrm{Sr}$ and $\mathrm{Pb}$ isotope studies of Cenozoic basalts in SE China, mantle sources, regional variations, and tectonic significance, Chem. Geol. 171, 33-47. 